\title{
Carbon monoxide down-regulates a $4 \beta 1$ integrin-specific ligand binding and cell adhesion: a possible mechanism for cell mobilization
}

\author{
Alexandre Chigaev ${ }^{1,2,3^{*}}$, Yelena Smagley ${ }^{1,2,3}$ and Larry A Sklar ${ }^{1,2,3}$
}

\begin{abstract}
Background: Carbon monoxide (CO), a byproduct of heme degradation, is attracting growing attention from the scientific community. At physiological concentrations, CO plays a role as a signal messenger that regulates a number of physiological processes. CO releasing molecules are under evaluation in preclinical models for the management of inflammation, sepsis, ischemia/reperfusion injury, and organ transplantation. Because of our discovery that nitric oxide signaling actively down-regulates integrin affinity and cell adhesion, and the similarity between nitric oxide and CO-dependent signaling, we studied the effects of $\mathrm{CO}$ on integrin signaling and cell adhesion.
\end{abstract}

Results: We used a cell permeable CO releasing molecule (CORM-2) to elevate intracellular CO, and a fluorescent Very Late Antigen-4 (VLA-4, $a_{4} \beta_{1}$-integrin)-specific ligand to evaluate the integrin state in real-time on live cells. We show that the binding of the ligand can be rapidly down-modulated in resting cells and after inside-out activation through several $\mathrm{Ga}_{\mathrm{i}}$-coupled receptors. Moreover, cell treatment with hemin, a natural source of $\mathrm{CO}$, resulted in comparable VLA-4 ligand dissociation. Inhibition of VLA-4 ligand binding by CO had a dramatic effect on cell-cell interaction in a VLA-4/NCAM-1-dependent cell adhesion system.

Conclusions: We conclude that the CO signaling pathway can rapidly down-modulate binding of the VLA-4 -specific ligand. We propose that CO-regulated integrin deactivation provides a basis for modulation of immune cell adhesion as well as rapid cell mobilization, for example as shown for splenic monocytes in response to surgically induced ischemia of the myocardium.

Keywords: Carbon monoxide, Hemin, Integrin, Affinity, Conformation, Cell adhesion

\section{Background}

Since the discovery that endogenous CO can serve as a neurotransmitter [1] and that it exhibits anti-inflammatory properties [2] the number of papers devoted to CO signaling and therapeutic applications has increased every year [3-6]. Since the roles of the two major gaseous messengers, $\mathrm{CO}$ and nitric oxide (NO) are somewhat similar [7], and our recent discovery of rapid effects of $\mathrm{NO}$ on integrin ligand binding affinity and cell adhesion [8], we studied the effects of $\mathrm{CO}$ on integrin regulation.

\footnotetext{
* Correspondence: achigaev@salud.unm.edu

'Department of Pathology and University of New Mexico Cancer Center,

Albuquerque, NM 87131, USA

2University of New Mexico Center for Molecular Discovery, Albuquerque, NM 87131, USA

Full list of author information is available at the end of the article
}

Integrins are cell adhesion receptors that are capable of modulating rapid adhesion and de-adhesion events, without a change in the number of molecules expressed [9]. Ligand interactions with integrins represent the molecular basis of integrin-dependent cell adhesion. Integrin-dependent cell adhesion is controlled by the conformational state of the molecule through ligand binding affinity and extension that are regulated by a number of signaling pathways initiated by other cellular receptors. This so-called inside-out signaling serves as the basis for rapid leukocyte arrest on endothelium, cell migration and chemotaxis, mobilization, trafficking, and interaction of immune cells $[10,11] . \alpha_{4} \beta_{1}$-integrin $(C D 49 \mathrm{~d} /$ CD29, Very Late Antigen-4, VLA-4) is expressed on leukocytes, dendritic cells, hematopoietic progenitors, and stem cells, as well as cancer cells of differing origin $[12,13]$. The goal of the current study was to examine the effects 
of the CO signaling pathway on VLA-4 conformational regulation.

To date, a limited number of studies have been dedicated to the effects of $\mathrm{CO}$ on leukocyte integrin-dependent adhesion. The down-regulation of leukocyte extravasation and leukocyte endothelial cell interaction, as well as the effects on integrin or integrin ligand expression have been reported [14-19]. To the best of our knowledge, this report represents the first time that the effects of $\mathrm{CO}$ and a natural source of $\mathrm{CO}$, hemin, on integrin ligand binding have been studied on live cells in real-time under insideout signaling conditions. Our findings provide a molecular mechanism for inhibition of integrin-dependent leukocyte adhesion and the beneficial effects of CO-associated therapies in a number of pathologies [4].

\section{Results}

\section{Carbon monoxide signaling and pathway modulation}

Endogenous $\mathrm{CO}$ is produced inside cells as a product of enzymatic degradation of heme catalyzed by the enzyme heme oxygenase $(\mathrm{HO})$ that consists of two isoforms: $\mathrm{HO}-1$ is inducible, and HO-2 is a constitutive form [20]. $\mathrm{HO}$ is localized in the cytosol and mitochondria [21]. The major source of heme for $\mathrm{CO}$ production is hemoglobin, and other hemeproteins (Figure 1). $\mathrm{CO}$ has been shown to stimulate soluble guanylyl cyclase, stimulate vasodilatation, block cell proliferation, participate in neural transmission, and inhibit platelet aggregation (see [20] and references therein). CO targets several heme-containing proteins and soluble guanylyl cyclase (sGC) was recognized as the first and the most studied "CO receptor". Multiple physiological effects including vasodilatation and platelet aggregation are attributed to the cGMP/PKG-dependent arm of the $\mathrm{CO}$ signaling pathway. Other signaling molecules such as p38 MAPK, ERK1/2, and JNK can be regulated through other "CO sensors" $[20,22]$.

To study the effects of CO/cGMP signaling in leukocytes, we selected several small molecules that specifically target this pathway (Figure 1). Tricarbonyldichlororuthenium (II) dimer, Carbon Monoxide-Releasing Molecule 2 (CORM-2), can be described as a complex of a transition metal ruthenium with carbon monoxide [23]. It spontaneously releases $\mathrm{CO}$ and is used as a carbon monoxide donor. It exerts a vasodilatory effect in isolated blood vessels, [24]. CORM-2 in vivo is shown to diminish adhesion and accumulation of PMNs in injured mice [25,26]. Hemin is a heme substrate analog and an inducer of HO-1 expression [19]. The conversion of one molecule of heme into biliverdin results in the release of one molecule of $\mathrm{CO}$. The $\mathrm{HO}$ enzyme that generates $\mathrm{CO}$ from hemin is expressed in our model system, and hemin addition has been shown to decrease pro-inflammatory cytokine levels in U937 cells [27]. BAY 41-2272 is an activator of soluble guanylyl cyclase, which was shown to stimulate cGMP

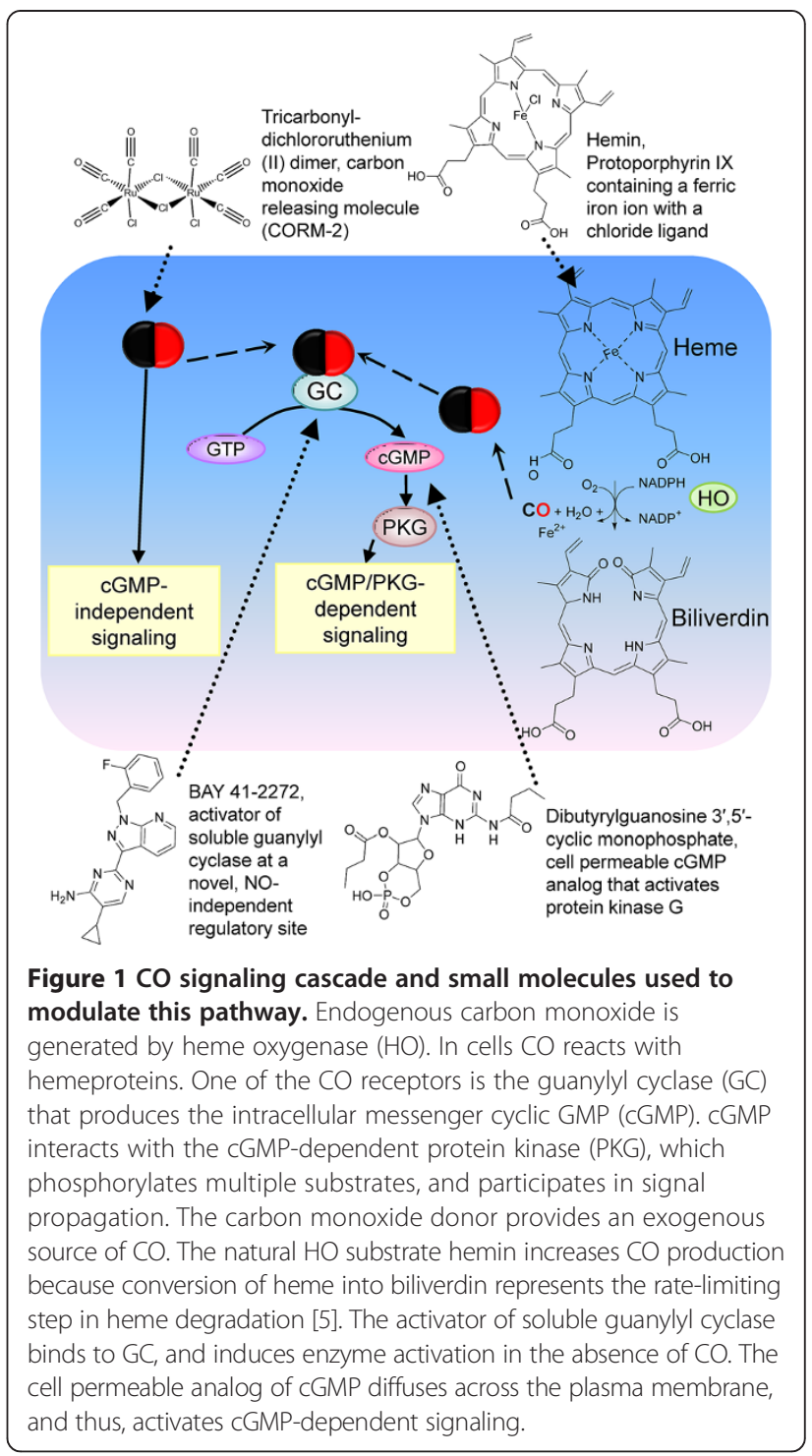

production [28]. $\mathrm{N}^{2}, 2^{\prime}$-O-dibutyrylguanosine 3',5'-cyclic monophosphate is a cell permeable cGMP analog that activates protein kinase G [29]. All these molecules are shown to stimulate different steps of the signaling pathway (Figure 1), and therefore, are used to mimic $\mathrm{CO}$ dependent signaling.

\section{The $\mathrm{CO}$ donor induces a rapid decrease in the binding of the VLA-4 specific ligand}

The VLA-4-specific ligand (LDV-FITC) is a small fluorescent probe based on the published structure of BIO1211, a CD49d/CD29 specific antagonist [30-32]. The molecule contains the Leu-Asp-Val (LDV) ligand binding motif from the alternatively spliced connecting segment-1 (CS-1) peptide of fibronectin. The major advantage of this probe is that it can be used to detect VLA-4 conformational changes on live cells in real-time in response to cell signaling 
$[8,33,34]$. The binding affinity detected using LDV-FITC varies in parallel with VCAM-1, the major natural VLA-4 ligand [35]. VCAM-1 contains the Ile-Asp-Ser (IDS) motif homologous to LDV, and VLA-4 interaction with VCAM-1 can be blocked by LDV-containing molecules [35-37]. To determine the effect of the $\mathrm{CO}$ donor on resting cells, samples were first treated with $25 \mathrm{nM}$ LDV-FITC (Figure 2A). This concentration is about 2 fold higher than the dissociation constant for LDV-FITC binding to U937 cells without activation $\left(\mathrm{K}_{\mathrm{d}} \sim 12 \mathrm{nM}\right.$, [30]). Therefore, $70-80 \%$ of low affinity sites are occupied. Next, the addition of CORM-2 resulted in the dose-dependent dissociation of LDV-FITC that reached a steady-state 5-6 min after addition. Finally, an excess of unlabeled competitor (LDV) was added to determine the non-specific binding of the probe (Figure 2A). This induced rapid LDV-FITC dissociation with a rate $\left(\mathrm{k}_{\mathrm{off}}\right)$ similar to the rate reported for resting cells [35]. To determine the EC50 for the effect of CORM-2 on LDV-FITC binding, the span of the single exponential fits for the dissociation curves after LDV addition was plotted versus the logarithm of CORM-2 concentration (Figure 2B).

Next, to study the effect of the CO donor on cells activated through the "inside-out" signaling pathway, we used U937 cells stably transfected with the non-desensitizing mutant of the formyl peptide receptor (FPR). Because serine and threonine in the C-terminal tail of GPCRs phosphorylated by $\mathrm{G}$ protein-coupled receptor kinases upon ligation are critical for the binding of arrestin and receptor desensitization [38,39], we used a mutant FPR lacking all serines and threonines (FPR $\triangle \mathrm{ST}$ ) [40]. After ligation of this receptor with a high affinity ligand $\mathrm{N}$ formyl-Met-Leu-Phe-Phe FPR signaling persists and the high affinity of the VLA-4 ligand binding pocket is maintained for thousands of seconds $[8,34]$.

To observe real-time inside-out VLA-4 activation, cells were first treated with $4 \mathrm{nM}$ LDV-FITC (Figure 2C). This concentration is below the dissociation constant $\left(\mathrm{K}_{\mathrm{d}}\right)$ for its binding to resting VLA-4 (low affinity state, $\mathrm{K}_{\mathrm{d}} \sim 12 \mathrm{nM}$ ), and above the $\mathrm{K}_{\mathrm{d}}$ for physiologically activated VLA-4 (high affinity state, $\mathrm{K}_{\mathrm{d}} \sim 1-2 \mathrm{nM}$ ) [30]. Thus, the transition from the low affinity to the high affinity receptor state led to increased binding of the probe (from $\sim 25 \%$ to $\sim 70-80 \%$ of receptor occupancy) [41]. Therefore, the binding of additional LDV-FITC molecules is detected as a rapid increase in the cell fluorescence. Because the laser of the flow cytometer excites only a small volume of solution around the cell, the detection of probe binding is possible in a homogeneous (no-wash) format $[42,43]$. Next, the addition of CORM-2 resulted in the dose-dependent dissociation of LDV-FITC. Excess unlabeled competitor (LDV) was used to determine the non-specific binding of the probe (Figure $2 \mathrm{C})$. The LDV-FITC dissociation rate $\left(\mathrm{k}_{\text {off }}\right)$ was slower but similar to the rate reported for cells activated through inside-out GPCR signaling [30,35]. The EC50 for the effect of CORM-2 on activated cells was somewhat higher than for resting cells (Figure 2D).

To establish whether the effect of CORM-2 was mediated by $\mathrm{CO}$, we conducted two control experiments (Figure 2E, F). First, cells were treated with $\mathrm{RuCl}_{3}$ at a concentration equal to the highest concentration used of CORM-2 (150 $\mu \mathrm{M}) . \mathrm{RuCl}_{3}$ is a product of CORM-2 degradation, and therefore, it was used as a negative control in CORM-2 experiments [44-47]. No statistically significant effects of $\mathrm{RuCl}_{3}$ on LDV-FITC binding or dissociation were detected (Figure 2E).

As a second control we took advantage of the limited stability of CORM molecules [48]. First, a stock solution of CORM-2 was prepared and incubated at room temperature for 48 hours. The effect of this old solution was compared to a fresh equimolar CORM-2 solution prepared prior to the experiment (Figure 2F). The freshly prepared solution induced significantly higher dissociation. Thus, because gaseous $\mathrm{CO}$ is released into the air over time, the difference between fresh and old CORM-2 solution may be attributed to the lower concentration of $\mathrm{CO}$ in the old solution. Based on the two controls we concluded that the effect of CORM-2 is attributed to $\mathrm{CO}$ released by the $\mathrm{CO}$ donor.

\section{Effect of the CO donor on the binding of VLA-4 specific ligand during inside-out activation through CXCR4 and CXCR2}

Cell activation through wild type GPCRs induces a rapid and reversible VLA-4 affinity change due to receptor desensitization [30]. Therefore, in CXCR4 and CXCR2 experiments, the $\mathrm{CO}$ donor was added two minutes prior to the addition of GPCR ligands (Figure 3). The treatment of cells stably transfected with wild type CXCR4 or CXCR2 significantly decreased the amplitude of the ligand-induced LDV-FITC response. Thus, similar to a non-desensitizing mutant of FPR the effect of the CO donor can be observed for signaling through other G-protein coupled receptors. This result is similar to the previously reported effect of NO on GPCR-induced VLA-4 activation [8].

Hemin, a natural substrate of $\mathrm{HO}$ and a natural source of CO, rapidly decreases binding of the VLA-4 specific ligand Heme oxygenase is expressed in U937 cells [49-51], and exogenous hemin can be used to modulate cell signaling in this cell line $[27,52]$. To study the effect of hemin on LDV-FITC binding on resting and activated cells, experiments were conducted in a manner similar to the $\mathrm{CO}$ donor experiments (Figure 2). Resting U937 cells were treated with 25 nM LDV-FITC (Figure 4A). Next, appropriate concentrations of hemin were added. We observed a slow dose-dependent decrease in the LDV-FITC signal. 


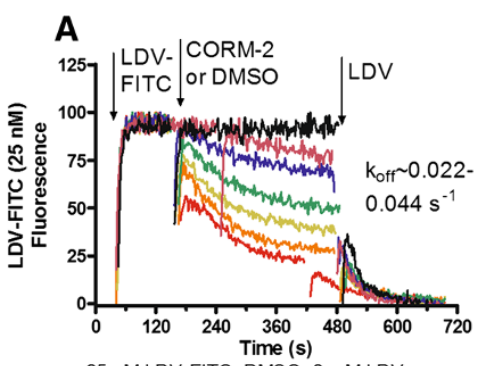

$25 \mathrm{nM}$ LDV-FITC, DMSO, $2 \mu \mathrm{M}$ LDV $-25 \mathrm{nM}$ LDV-FITC, $4.7 \mu \mathrm{M}$ CORM-2, $2 \mu \mathrm{M}$ LDV $25 \mathrm{nM}$ LDV-FITC, $9 \mu \mathrm{M}$ CORM-2, $2 \mu \mathrm{M}$ LDV

$-25 \mathrm{nM}$ LDV-FITC, $19 \mu \mathrm{M}$ CORM-2, $2 \mu \mathrm{M}$ LDV

$25 \mathrm{nM}$ LDV-FITC, $38 \mu \mathrm{M}$ CORM-2, 2 $\mu \mathrm{M}$ LDV

25 nM LDV-FITC, $75 \mu$ M CORM-2, $2 \mu$ MLDV

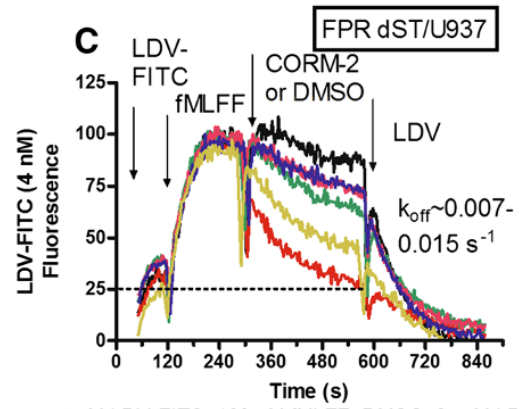

-4 nM LDV-FITC, 100 nM fMLFF, DMSO, $2 \mu \mathrm{M}$ LDV

$-4 \mathrm{nM}$ LDV-FITC, $100 \mathrm{nM}$ fMLFF, $9 \mu \mathrm{M}$ CORM-2, $2 \mu \mathrm{M}$ LDV

-4 nM LDV-FITC, 100 nM fMLFF, $19 \mu \mathrm{M}$ CORM-2, $2 \mu \mathrm{M}$ LDV

$-4 \mathrm{nM}$ LDV-FITC, $100 \mathrm{nM}$ fMLFF, $38 \mu \mathrm{M}$ CORM-2, $2 \mu \mathrm{M}$ LDV

$-4 \mathrm{nM}$ LDV-FITC, $100 \mathrm{nM}$ fMLFF, $75 \mu \mathrm{M}$ CORM-2, $2 \mu \mathrm{M}$ LDV

$4 \mathrm{nM}$ LDV-FITC, $100 \mathrm{nM}$ fMLFF, $150 \mu \mathrm{M}$ CORM-2, $2 \mu \mathrm{M}$ LDV

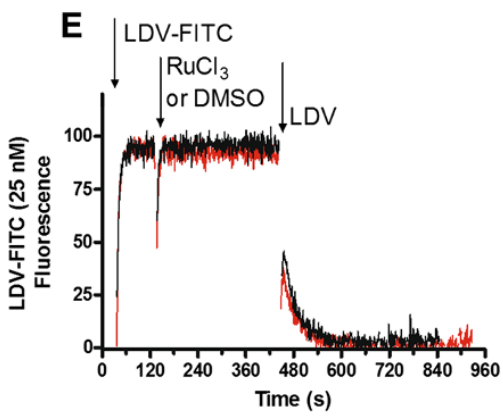

$-25 \mathrm{nM}$ LDV-FITC, $150 \mu \mathrm{M} \mathrm{RuCl}{ }_{3}, 1 \mu \mathrm{M}$ LDV

$-25 \mathrm{nM}$ LDV-FITC, DMSO, $1 \mu \mathrm{M}$ LDV
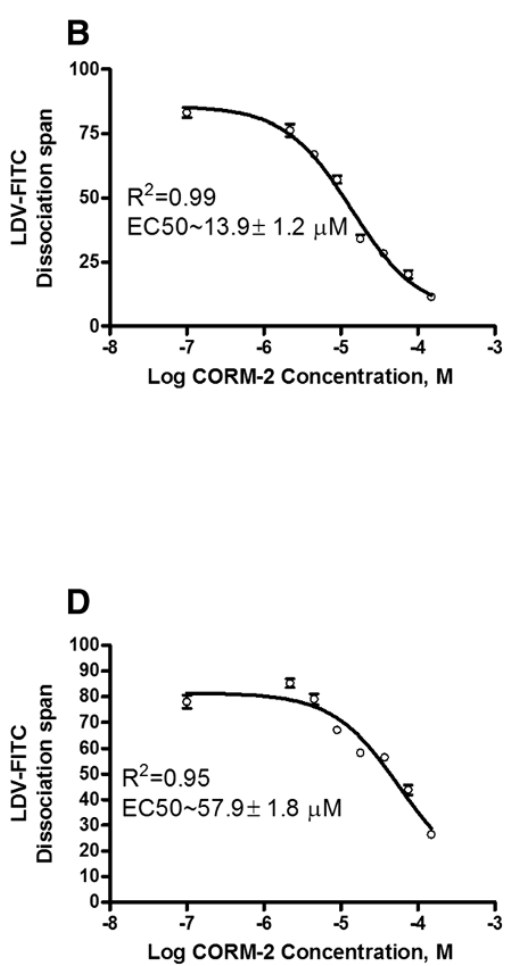

Figure 2 Effect of CO donor on binding and dissociation of the LDV-FITC probe on resting and activated cells. LDV-FITC binding and dissociation on U937 cells stably transfected with the non-desensitizing mutant FPR $\Delta$ ST plotted as LDV-FITC fluorescence versus time. The data were normalized to the level of the non-specific signal determined by addition of excess unlabeled competitor (LDV), and therefore, no autofluorescence can be seen. $\mathbf{A}$. The experiment involved sequential additions of the LDV-FITC, and different concentrations of CORM-2 or vehicle. The non-specific binding of the probe was determined using LDV. Ligand dissociation rates $\left(k_{\text {off }}\right)$ were determined by fitting the dissociation part of the curves to the single exponential equation. B. The span of the single exponential fits for the dissociation curves (from A after LDV addition) plotted versus logarithm of CORM-2 concentration. Means \pm SEM of two independent determinations are shown. The sigmoidal dose-response (Hill slope $=1)$ was fit using

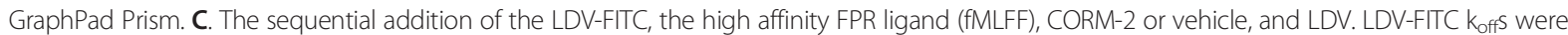
determined as described for A. The level of LDV-FITC binding corresponding to resting cells is indicated by the dashed line. D. The span of single exponential fits for the curves (from panel $\mathbf{C}$ ) plotted versus logarithm of CORM-2 concentration. Means \pm SEM of two independent determinations are shown. The dose-response was fit analogously to B. $\mathbf{E}$. The experiment involved addition of the LDV-FITC, RuCl ${ }_{3}$ or vehicle. F. The sequential addition of the LDV-FITC, and CORM-2. The "old" CORM-2 was prepared by incubating the solution for 48 hours at room temperature. The non-specific binding of the LDV-FITC probe was determined using LDV. For panels $\mathbf{A}, \mathbf{C}, \mathbf{E}$, and $\mathbf{F}$, a representative experiment of two independent experiments is shown. 

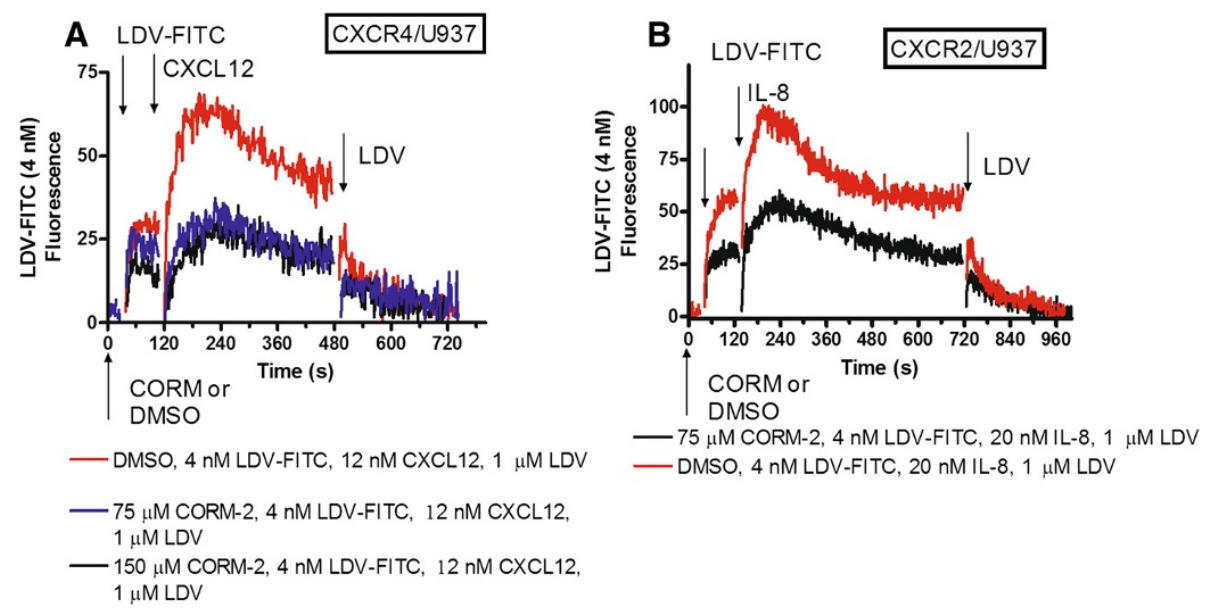

Figure 3 Effect of CO donor pretreatment on binding and dissociation of the LDV-FITC probe in cells stably transfected with CXCR4 and CXCR2, then treated with different Gai-coupled receptor ligands. A. The experiment involved sequential addition of CORM-2 (75-150 $\mu$ M, CO donor) or DMSO (control), the fluorescent LDV-FITC probe (4 nM), CXCL12/SDF-1 (12 nM), and excess unlabeled LDV competitor (1 $\mu \mathrm{M})$. Rapid and reversible binding of the probe reflects the VLA-4 affinity change. B. The experiment involved sequential addition of CORM-2 (75 $\mu \mathrm{M}, \mathrm{CO}$ donor) or DMSO (control), the fluorescent LDV-FITC probe $(4 \mathrm{nM}), \mathrm{CXCL} / \mathrm{IL}-8$ ( $20 \mathrm{nM})$, and excess unlabeled LDV competitor $(1 \mu \mathrm{M})$. A representative experiment of two independent experiments is shown.

Finally, to determine the non-specific binding of the LDV-FITC probe, excess unlabeled competitor was added 10-12 min later. As in the case of the CO donor, the ligand dissociation rate $\left(\mathrm{k}_{\text {off }}\right)$ was similar to the rate reported for resting cells. To determine the EC50 for the effect of hemin on LDV-FITC binding, the span of single exponential fits for the dissociation curves after LDV addition was plotted versus the logarithm of hemin concentration (Figure 4B). The effect of hemin was similar to the effect of the $\mathrm{CO}$ donor on resting cells.

The effect of hemin on "inside-out" activated cells (Figure 4C) has been studied in a manner analogous to the $\mathrm{CO}$ donor experiments (Figure 2C). Cells were treated with LDV-FITC, FPR ligand for cell activation, appropriate concentrations of hemin, and the unlabeled LDV competitor (Figure 4C). Analogous to the $\mathrm{CO}$ donor results, the ligand dissociation rate $\left(\mathrm{k}_{\text {off }}\right)$ was similar to the rate reported for activated cells, and the EC50 for the effect of hemin on activated cells was comparable to the EC50 for resting cells (Figure 4D). Thus, the natural source of $\mathrm{CO}$, hemin, exhibited activity that was analogous to that of the artificial $\mathrm{CO}$ donor. Both compounds induced rapid dissociation of the VLA-4 specific ligand.

\section{Carbon monoxide donor produces a small effect on VLA-4 subunit surface expression}

To study the effect of CO signaling on VLA-4 surface expression, cells were treated with the $\mathrm{CO}$ donor or vehicle for $30 \mathrm{~min}$ at $37^{\circ} \mathrm{C}$. Next, cells were stained with primary labeled antibody against $\alpha 4$ - and $\beta 1$-integrin subunits (Figure 5). Analysis of antibody binding revealed a decrease in the surface expression of both integrin subunits that varied from $10 \%$ to $26 \%$ in multiple experiments. Given the small sample to sample variation this difference was statistically significant (Figure 5B). However, this difference in the expression of VLA-4 subunits detected after $30 \mathrm{~min}$ of $\mathrm{CO}$ donor treatment cannot account for rapid and dramatic decrease in the VLA-4specific ligand binding that has been detected after $\mathrm{CO}$ donor addition (Figure 2B,C).

\section{Carbon monoxide donor diminishes VLA-4 /VCAM-1- dependent cell adhesion}

Next, to study the implications of the $\mathrm{CO}$ signaling pathway on integrin-dependent cell adhesion, we utilized a VLA-4/ VCAM-1-specific real-time cell aggregation assay [35]. The specificity of cell aggregation in this model system was tested using anti- $\alpha 4$-integrin blocking $\mathrm{mAb}$ as well as unlabeled LDV that completely blocked cell aggregation $[35,53]$. Prior to mixing, U937 cells constitutively expressing VLA-4 were labeled with green fluorescent dye, and B78H1 cells stably transfected with human VCAM-1 were stained with red fluorescent dye (Figure 6A). The cell aggregates were detected as red and green co-fluorescent events in real-time. Cells were mixed and the baseline aggregation data were collected for the first three minutes. Next, the tube was removed and an aliquot of stock solution of carbon monoxide donor CORM-2 in DMSO or equal volume of vehicle (DMSO) were added. The tube was rapidly replaced and data acquisition was reestablished. The data were collected for up to $30 \mathrm{~min}$ (Figure 6B).

The CO donor treatment was sufficient to fully reverse cell aggregation (Figure 6B). During the first three minutes of the experiment no significant difference between the 

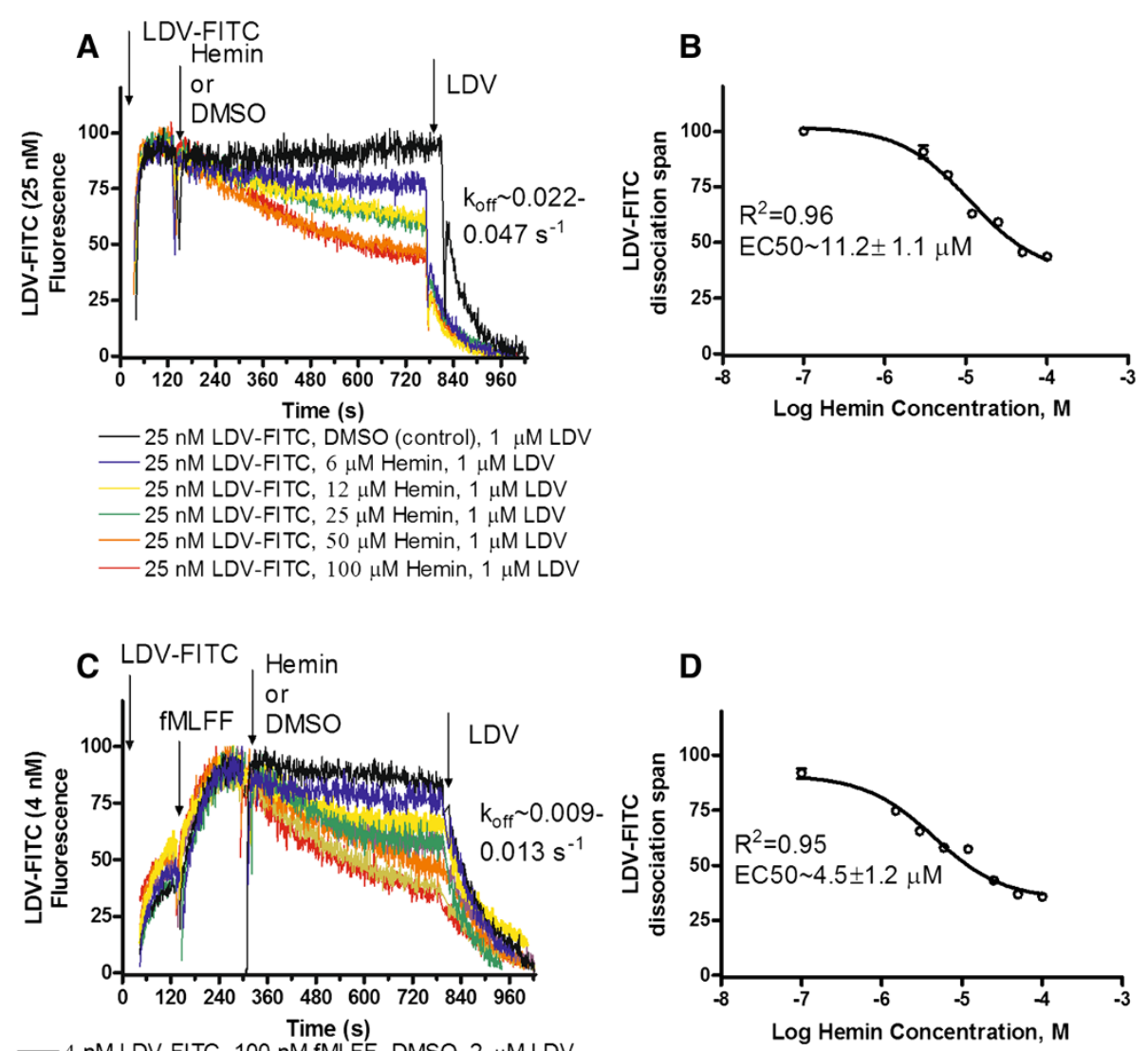

D

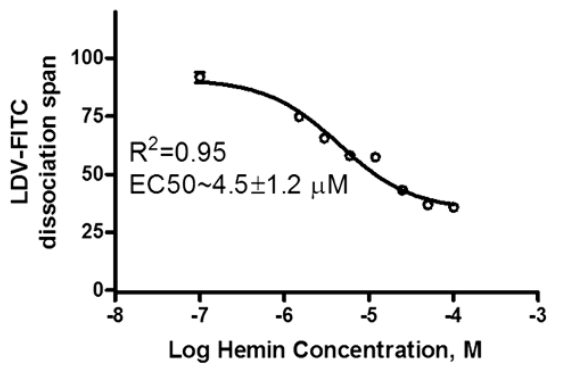

$-4 \mathrm{nM}$ LDV-FITC, $100 \mathrm{nM}$ fMLFF, DMSO, $2 \mu \mathrm{M}$ LDV
$-4 \mathrm{nM}$ LDV-FITC, $100 \mathrm{nM}$ fMLFF, $1.5 \mu \mathrm{M}$ Hemin, $2 \mu \mathrm{M}$ LDV

$-4 \mathrm{nM}$ LDV-FITC, $100 \mathrm{nM}$ fMLFF, $3 \mu \mathrm{M}$ Hemin, $2 \mu \mathrm{M}$ LDV

$-4 \mathrm{nM}$ LDV-FITC, $100 \mathrm{nM}$ fMLFF, $6 \mu \mathrm{M}$ Hemin, $2 \mu \mathrm{M}$ LDV

4 nM LDV-FITC, 100 nM fMLFF, $12 \mu$ M Hemin, $2 \mu \mathrm{M} \mathrm{LDV}$

$-4 \mathrm{nM}$ LDV-FITC, $100 \mathrm{nM}$ fMLFF, $25 \mu \mathrm{M}$ Hemin, $2 \mu \mathrm{M}$ LDV

4 nM LDV-FITC, 100 nM fMLFF, $50 \mu$ M Hemin, $2 \mu \mathrm{M} \mathrm{LDV}$

- 4 nM LDV-FITC, 100 nM fMLFF, $100 \mu$ M Hemin, $2 \mu \mathrm{M}$ LDV

Figure 4 Effect of hemin on binding and dissociation of the LDV-FITC probe on resting and activated U937 cells. LDV-FITC probe binding and dissociation on U937 cells plotted as LDV-FITC fluorescence versus time. The data were normalized to the level of the non-specific signal determined by the addition of excess unlabeled competitor (LDV $2 \mu \mathrm{M})$, and therefore, no cell autofluorescence can be seen. $\mathbf{A}$. The experiment involved sequential addition of the fluorescent LDV-FITC probe ( $25 \mathrm{nM}$ ), and different concentrations of hemin (6-100 $\mu \mathrm{M}$ ) or DMSO (vehicle). The non-specific binding of the LDV-FITC probe was determined using excess unlabeled competitor (LDV). Ligand dissociation rates ( $\left.k_{\text {off }}\right)$ were determined by fitting the dissociation part of the curves (after LDV addition) to the single exponential equation. The range of $\mathrm{k}_{\text {off }}$ is shown. $\mathbf{B}$. The span of the single exponential fits for the dissociation curves (from panel A after LDV addition) plotted versus logarithm of hemin concentration. Means \pm SEM of two independent determinations are shown $(n=2)$. The sigmoidal dose-response fit (Hill slope $=1$ ) was obtained using GraphPad Prism software. $\mathbf{C}$. The experiment was conducted using U937 cells stably transfected with the FPR $\Delta$ ST receptor, and involved sequential addition of the fluorescent LDV-FITC probe (4 nM), the high affinity FPR

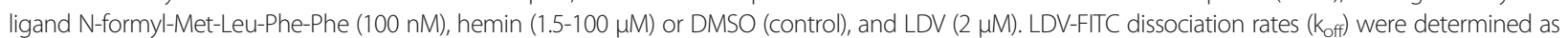
described for panel A. D. The span of the single exponential fits for the dissociation curves (from panel C, after LDV addition) plotted versus logarithm of hemin concentration. Means \pm SEM of two independent determinations are shown $(n=2)$. The sigmoidal dose-response fit was obtained analogously to panel $\mathbf{B}$.

two samples was detected. After the addition of CORM-2, cells continued to aggregate for $\sim 2$ minutes, and then aggregate accumulation stopped and disaggregation occurred. The sample treated with vehicle exhibited a long-term accumulation of cell aggregates that reached $30-40 \%$ by the end of the experiment (Figure 6B). The difference between samples treated with the $\mathrm{CO}$ donor and untreated samples was statistically significant (Figure 6C).
Thus, the CO donor added to the cell suspension in realtime prevented VLA-4/VCAM-1-dependent aggregation.

\section{The carbon monoxide donor decreases the binding} affinity of the VLA-4 specific ligand

Next, to quantify the effect of CO on VLA-4 specific ligand binding affinity, we evaluated the binding of unlabeled LDV ligand using a Ligand Induced Binding Site (LIBS) antibody. 

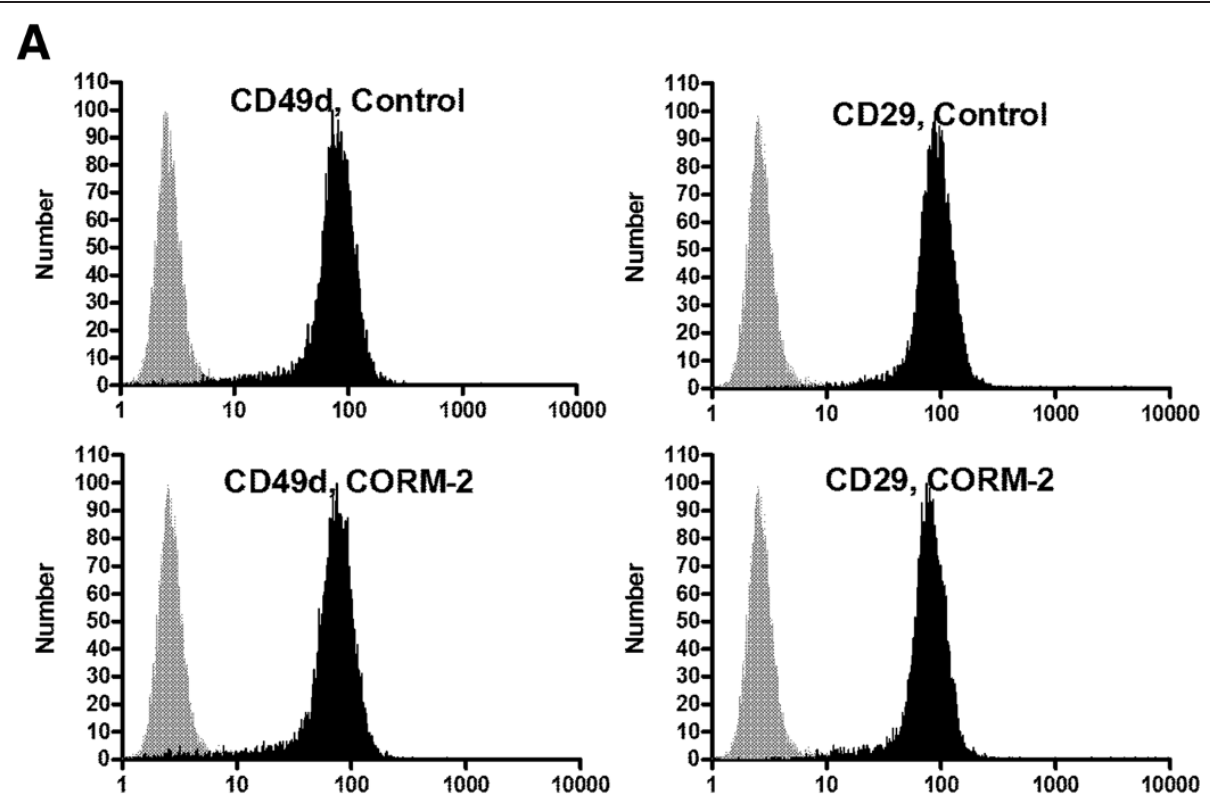

\section{B}

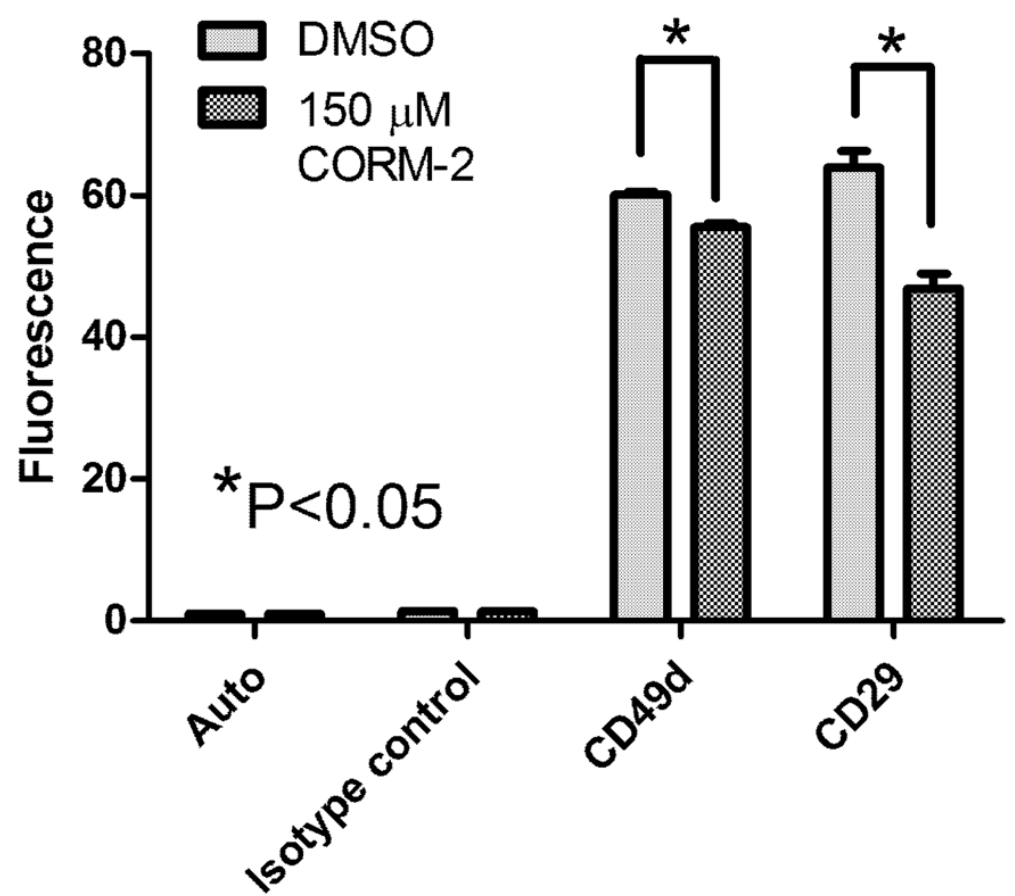

Figure 5 Effect of CO donor on surface expression of VLA-4 (CD49d/CD29 heterodimer). U937 cells were treated with vehicle (DMSO, control), and CO donor (150 $\mu \mathrm{M}$ CORM-2) for $30 \mathrm{~min}$ at $37^{\circ} \mathrm{C}$. Next, cells were placed on ice and stained with primary labeled anti-CD29 and anti-CD49d antibodies, or the isotype control. A. Histograms of anti-CD29 and anti-CD49d antibodies are shown in black, and the isotype control is grey. B. Bar graphs of mean channel fluorescence (MCF) \pm SEM $(n=5)$ for unstained cells (autofluorescence), nonspecific binding to cells (isotype control), cells treated with vehicle (DMSO), and cells treated with CORM-2 are shown (10,000 gated events for each sample were collected). One representative experiment of three experiments is shown. ${ }^{*}$ indicates means are significantly different $(P<0.05)$ as estimated by the unpaired t test analysis using GraphPad Prism software.

Binding of ligands to integrins induces a series of conformational changes that result in the exposure of previously hidden epitopes. A LIBS antibody can recognize these epitopes. This $\mathrm{mAb}$ feature can be used to detect ligand occupied integrin receptors. The parental ligand molecule (BIO1211) [32], and the LDV ligand are known to induce 


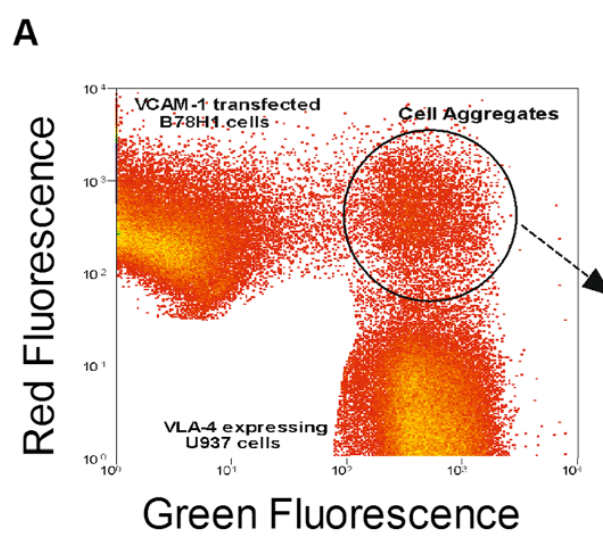

\section{B}
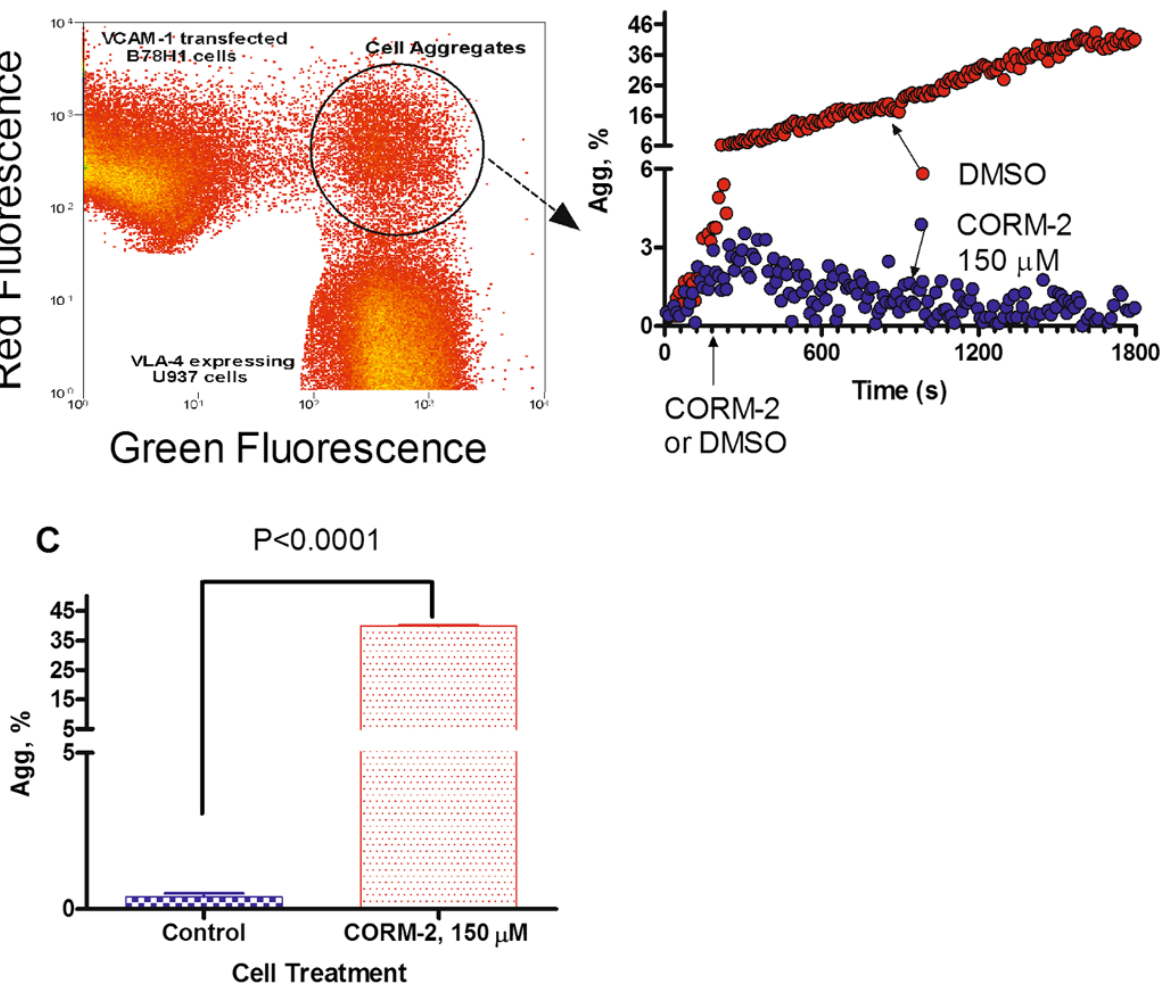

Figure 6 Effect of CO donor on cell adhesion between U937 cells and VCAM-1-transfected B78H1 cells. A. Dot plot of flow cytometric analysis of cell aggregation. Cells were labeled with red and green fluorescent dyes. Next, cells were mixed at 0 time point. During data acquisition samples were maintained at $37^{\circ} \mathrm{C}$, and continuously stirred with a magnetic stir bar. An increase in the number of aggregates was detected as green and red co-fluorescent particles indicated by the circular gate. B. Real-time cell aggregation plotted as \% aggregates (Agg, \%) versus time. The data were normalized to the non-specific aggregation determined as cell aggregation in the presence of excess unlabeled competitor (1 $\mu \mathrm{M}$ LDV). A representative experiment out of two experiments is shown. C. Statistical significance of the CO donor effect on cell aggregation. The aggregate percentage data from the last 5 min of the experiments $(B)$ are compared using the unpaired t test. Means are significantly different $(P<0.05)$.

LIBS epitopes [41,54]. To determine the ligand binding affinity $\left(\mathrm{K}_{\mathrm{d}}\right)$ for the unlabeled molecule, cells are incubated with increasing concentrations of the ligand in the presence of a constant concentration of the primary labeled LIBS $\mathrm{mAb}$ [33]. Because flow cytometers have the ability to discriminate between free and bound fluorescent molecules in a homogeneous assay [42], the concentration of the unlabeled ligand-receptor complex is proportional to the fluorescence of the fluorophores associated with the mAbs [54]. The major advantage of this approach, compared with direct binding of a fluorescent ligand, is that there is no limit to the ligand concentration. Because the LDV ligand is unlabeled, no non-specific fluorescence increase with ligand concentration is observed, and virtually no nonspecific antibody binding is detected $[33,41,54]$. This assay allows the detection of integrin affinity changes that differ by several orders of magnitude [55].

Cells were incubated in the presence of increasing concentrations of unlabeled LDV and phycoerythrinlabeled anti-CD29 LIBS antibody (HUTS-21) in the presence or absence of the $\mathrm{CO}$ donor. As shown previously, the EC50 for $\mathrm{mAb}$ binding is similar to the ligand dissociation constant $\left(\mathrm{K}_{\mathrm{d}}\right)$ determined using other methods [54]. We observed that the EC50s for LIBS antibody binding for CORM-2 treated samples were larger than for the vehicle treated controls by $\sim 2$ fold for resting cells, and $\sim 3$ fold for FPR activated cells (Figure 6). This indicated a decrease in the ligand binding affinity. Also, the fact that the maximal binding of LIBS antibody for CORM-2 treated samples was $\sim 5-10 \%$ lower was suggested by the change in VLA-4 receptor surface expression (CD49d/CD29 complex) as detected using anti-CD49d and anti-CD29 antibodies (Figure 5).

To evaluate the effects of the $\mathrm{CO}$ donor on the affinity of the VLA-4 specific ligand we compared data obtained using fluorescent LDV-FITC (Figures 2A,C and 4A,C) with LDV binding detected using LIBS (Figure 7). Notice that the two highest concentrations of the $\mathrm{CO}$ donor or hemin induced very similar effects (see Figures $2 \mathrm{~A}$ and 4A). The decrease in LDV-FITC binding on resting cells saturated at $\sim 30 \%$ for both compounds. Quantitatively, in order to observe a decrease from $68 \%$ occupancy for 

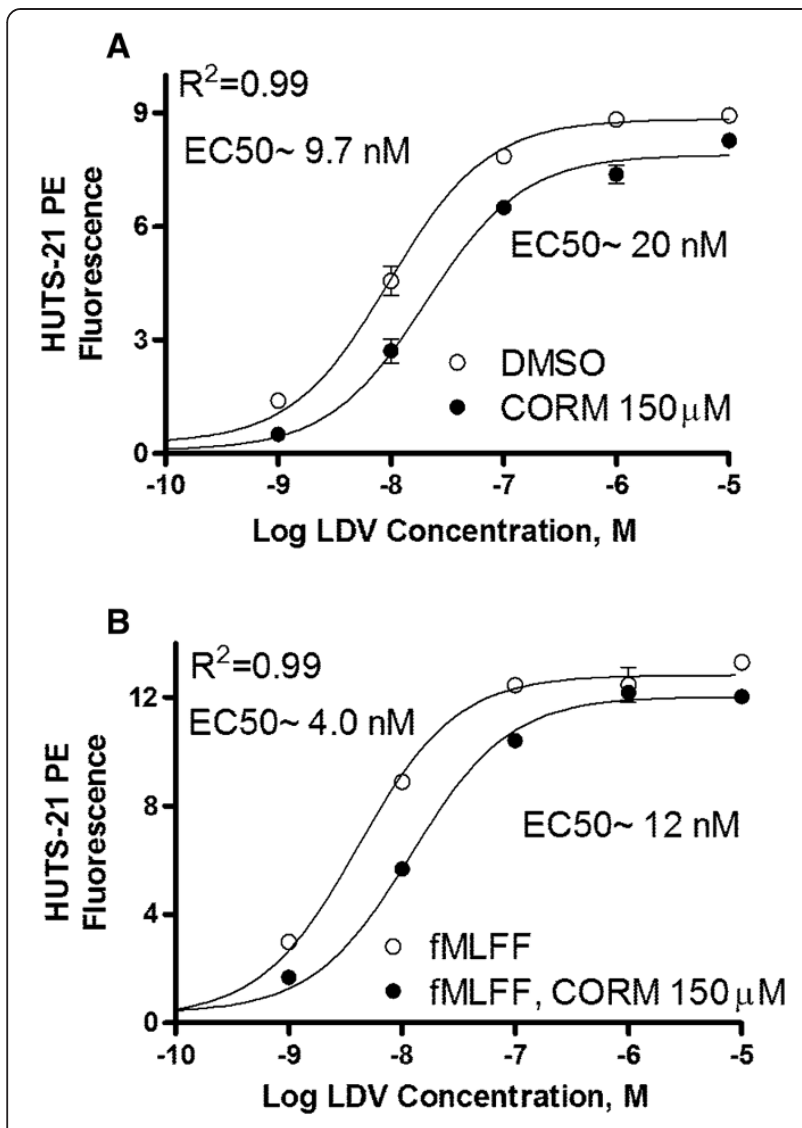

Figure 7 Effect of $\mathrm{CO}$ donor on binding of primary labeled LIBS (HUTS-21) to U937 cells in the presence of different concentrations of LDV. Mean fluorescence intensity plotted versus concentration of unlabeled LDV. A. U937 cells were treated with vehicle (DMSO, control), and $\mathrm{CO}$ donor (150 $\mu \mathrm{M}$ CORM-2) for $30 \mathrm{~min}$ at $37^{\circ} \mathrm{C}$. Next, cells were incubated with the indicated concentration of LDV in the presence of excess HUTS-21 mAbs, washed, and fluorescence was measured. B. U937 cells stably transfected with the non-desensitizing FPR mutant were treated with vehicle (DMSO, control), and CO donor (150 $\mu \mathrm{M}$ CORM-2) for $30 \mathrm{~min}$ at $37^{\circ} \mathrm{C}$ in the presence of $100 \mathrm{nM}$ fMLFF for cell activation. Next, mAb binding was performed in a manner analogous to $\mathrm{A}$. The non-specific binding of HUTS-21, detected in the absence of LDV ligand, was subtracted from the data. Means \pm SEM of three independent determinations are shown. The data were fitted using the sigmoidal doseresponse equation with GraphPad Prism software. One representative experiment out of three independent experiments is shown.

the binding of the LDV-FITC ligand on resting cells (the initial binding occupancy as calculated based on resting VLA-4 $\mathrm{K}_{\mathrm{d}} \sim 12 \mathrm{nM}$ [30], and LDV-FITC concentration $25 \mathrm{nM}$ ) to $\sim 30 \%$, a $\sim 4.8$ fold increase in the $\mathrm{K}_{\mathrm{d}}$ would be required (at $\mathrm{K}_{\mathrm{d}} \sim 58 \mathrm{nM}$, ligand concentration $25 \mathrm{nM}$, receptor occupancy $\sim 30 \%$ as derived from the one-site hyperbolic binding equation).

For FPR activated cells, a decrease from $\sim 80 \%$ initial occupancy $\left(\mathrm{K}_{\mathrm{d}} \sim 1 \mathrm{nM}\right.$, and LDV-FITC concentration $4 \mathrm{nM}$ ), down to $\sim 25 \%$ occupancy, requires a $\sim 12$ fold increase in the $\mathrm{K}_{\mathrm{d}}$ (at $\mathrm{K}_{\mathrm{d}} \sim 12 \mathrm{nM}$, ligand concentration $4 \mathrm{nM}$ ). This suggests that the effect of $\mathrm{CO}$ is more significant in the case of integrins activated through inside-out signaling. It is worth noting that $K_{d} \sim 12 \mathrm{nM}$ corresponds to the $\mathrm{K}_{\mathrm{d}}$ detected on resting cells, and the real-time decrease in LDV-FITC binding after CORM-2 addition reached a plateau at a level that was close to the level corresponding to the resting cell (before FPR activation, Figure $2 \mathrm{C}$ ). This observation additionally supports our calculations.

The effect of the $\mathrm{CO}$ donor on the ligand affinity change detected using the LIBS antibody was smaller. We detected only two to three fold differences in the EC50s (Figure 7). The EC50 for fMLFF activated cells (Figure 7B) was higher than the $\mathrm{K}_{\mathrm{d}}$ estimated using dissociation rate analysis $[30,35,56]$. This discrepancy may be attributed to desensitization of FPR signaling after long-term incubation in the presence antibodies. This data additionally emphasizes the importance of rapid real-time approaches for studying cell signaling [33].

The activator of soluble guanylyl cyclase and the cell permeable CGMP analog decrease the binding affinity of the VLA-4 specific ligand

The effects of BAY 41-2272, an activator of soluble guanylyl cyclase and dibutyrylguanosine 3',5'-cyclic monophosphate, a cell permeable cGMP analog, (Figure 1) were studied previously as part of our study of nitric oxide signaling and VLA-4 regulation [8]. We found that BAY 41-2272 induced a rapid dose-dependent down-regulation of LDV-FITC binding after activation through CXCR4, CXCR2, and the non-desensitizing mutant of FPR. Cell treatment with BAY 41-2272 exhibited faster dissociation rates $\left(\mathrm{k}_{\text {off }}\right)$ indicating a decrease of the affinity of the VLA-4 specific ligand. DbcGMP also induced rapid and dose dependent down-regulation of LDV-FITC binding [8]. Given the similarity between $\mathrm{NO}$ and $\mathrm{CO}$ signaling and their functional roles, both gases stimulate guanylyl cyclase [7,57]. These data support the role of the CO signaling pathway in regulating VLA-4 conformation and cell adhesion.

\section{Discussion}

Do cyclic nucleotides act as universal anti-adhesive integrin regulators?

During the last few years we have described two signaling pathways that can rapidly down-regulate the binding of the VLA-4 specific ligand and cell adhesion: the Goscoupled receptor signaling pathway and the NO/cGMP signaling pathway $[8,34]$. CO-mediated VLA-4 inactivation is described in this report. One common feature of these pathways is the modulation of nucleotide cyclases leading to up-regulation of cyclic nucleotide (cAMP and cGMP) levels. Similar downstream signaling mechanisms, related to nucleotide-dependent kinases [58] and other effectors, suggest the need for further evaluation of the 
role of cyclic nucleotide-dependent pathways in integrindependent cell de-adhesion. The literature reveals that these pathways can participate in cell mobilization, demargination, detachment, or deployment, all of which can be linked to a decrease of $\alpha 4$-integrin-dependent cell adhesion.

For Gos-coupled GPCRs, such as the $\beta 2$-adrenergic receptor or the $\mathrm{H} 2$-histamine receptor, specific ligand agonists and antagonists, as well as an adenylyl cyclase activator and a cell permeable cAMP analog were able to rapidly modulate the affinity of the integrin and cell adhesion after SDF-1/CXCR4 or FPR meadiated activation [34]. This signaling pathway may participate in demarginating nonclassical monocytes [59] and CD8+ effector T-cells [60], triggering rapid detachment of PBMCs attached to the endothelium [61], mobilizing natural killer cells [62-64], and playing a role in $\beta 2$-adrenergic receptor and cAMPinduced leukocytosis [65-67]. However, further studies are needed to dissect the interplay between cytokines and this signaling pathway [68]. Rapid mobilization of hematopoietic stem progenitor cells (HSPCs) mediated specifically through VLA-4 adhesion and SDF-1/CXCR4dependent signaling [55,69-75] was induced by $\beta 2$ adrenergic receptor agonists, and can be blocked by a specific antagonist in mice [76]. We envision that $\beta 2$-adrenergic receptor/cAMP-dependent VLA-4 deactivation [34] provides one of the molecular mechanisms for regulating stem progenitor cell egress from the bone marrow [77,78]. Another mechanism can be related to NO signaling.

Our discovery that the NO/cGMP signaling pathway rapidly deactivates high affinity VLA-4 pre-activated by SDF-1/CXCR4 signaling and other Goi-coupled GPCRs [8] provides a plausible explanation for the observation that links NO-mediated signaling and nitric oxide synthase with stem and progenitor cell trafficking and mobilization. Mice deficient in endothelial nitric oxide synthase (NOS3 or eNOS) exhibited impaired mobilization of endothelial progenitor cells (EPC) from the bone marrow. The expression of CD29 (VLA-4 $\beta 1$-subunit) and CXCR4 remained unaltered in $\mathrm{NOS}^{-1-}$ mice, but neither the conformation nor affinity state of the integrin was tested [79]. Bone marrow stromal and vascular cells express large quantities of NOS. These cells are envisioned to be a major source of NO. Both stromal and vascular cells express VEGFreceptor-2 (Flk-I), and VEGF is one of the major factors mobilizing endothelial progenitors from bone marrow $[80,81]$. VEGF has been shown to activate NO release through AKT-dependent phosphorylation of eNOS [80,82-85]. Thus, NO-triggered deactivation of VLA-4 could complement VEGF-induced stem cell mobilization (see Figure 3 in [82]). It is possible that the effect of $\mathrm{NO}$ is specific to CD34 $4^{+}$Flk- $\mathrm{I}^{+}$EPCs. Under NO-deficient conditions EPCs failed to be mobilized into the peripheral blood. The c-kit ${ }^{+} \mathrm{Lin}^{-}$HSPCs were not affected by nitric oxide [86]. Thus, existing data support specific role of cyclic nucleotide-related signaling as a regulator of cell mobilization, demargination, or detachment under Goscoupled GPCRs or NO signalling.

\section{$\mathrm{CO}$ in macrophages}

The effect of $\mathrm{CO}$ is typically attributed to the enzymatic catabolism of heme, and the majority of $\mathrm{CO}$ (up to $70 \%$ ) is produced from hemoglobin originating from the breakdown of erythrocytes [20]. Splenic red-pulp macrophages are responsible for the removal of senescent red blood cells from the circulation, during filtration of blood though the spleen [87]. These macrophages express heme oxygenase-1 (HO-1) that metabolizes heme and produces iron, biliverdin, and carbon monoxide [4]. HO-1 is essential for splenic macrophage function, since in $\mathrm{HO}^{-1-}{ }^{-1}$ mice macrophages are destroyed through exposure to unmetabolized heme [88]. At the same time, the spleen is reported to serve as a reservoir for resident macrophages that can be rapidly deployed in the peripheral blood in response to surgically induced ischemia of the myocardium [89]. The data presented in this report suggest a possible mechanism for the deployment phenomenon.

Erythrocyte damage can be induced by a number of factors that include ischemia and inflammation. This may lead to the increased clearance of red blood cells [90]. As a result, increased phagocytosis by splenic macrophages can lead to rapid up-regulation of heme catabolism and intra-macrophage $\mathrm{CO}$ production. This is expected to down-modulate integrin affinity and cell adhesion within the phagocyte. It is also possible that $\mathrm{CO}$ can diffuse from the phagocyte and act in a paracrine manner on macrophages residing in close proximity. The loss of cell adhesion could result in macrophages entering the circulation through the efferent splenic vein. This scenario seems plausible specifically because of the role of $\alpha 4$-integrins in splenic homing $[87,91]$.

Another possible implication of the anti-adhesive impact of $\mathrm{CO}$ signaling is in ischemia-reperfusion injury and transplantation [4]. Adhesion molecules and specifically $\beta 1$ - and $\beta 2$ - integrins are envisioned as feasible targets for preventing reperfusion injury through blocking leukocyte extravasation and recruitment [92-94]. The successful application of $\mathrm{CO}$ for organ transplant could be accompanied by reduced recruitment of leukocytes, macrophages, and T-cells to the graft [95], and the overall anti-inflammatory effect of $\mathrm{CO}$ could also be related to blocking integrin-dependent immune cell adhesion [4]. Thus, it seems that the enzymatic catabolism of heme in marcrophages and resulting intra-macrophage $\mathrm{CO}$ production are critical for rapid down-regulation of integrin-mediated cell adhesion, rapid re-entry of adherent cells into circulation, or blocking of leukocyte extravasation 
and recruitment to the sites of inflammation. We propose that therapeutic modulation of this pathway can serve as a viable alternative to a direct modulation of cell adhesion using integrin antagonists for example.

\section{$\mathrm{CO}$, integrins, and immune response}

The release and accumulation of hemin in peripheral blood can result from hemolysis that occurs as a consequence of bacterial infection [96]. Free heme plays a crucial role in the pathogenesis of sepsis [97]. Since VLA-4 and VLA-5 are known to regulate phagosome maturation and microorganism clearance in macrophages [98], the pathogen-induced damage of erythrocytes, which decreases integrin binding through activation of the CO/cGMP pathway, should promote pathogen survival. In particular, the lipopolysaccharide-binding pattern recognition molecule mindin (spondin-2) specifically interacts with CD49d/CD29 [99] though the LEV (Leu-Glu-Val) integrin-binding motif [100] homologous to the LDV (Leu-Asp-Val) binding motif in fibronectin [101]. Mindin is essential for microorganism clearance because mindin-deficient macrophages show defective phagocytosis [102]. Therefore, one would expect that the binding of mindin to VLA-4 will be regulated by $\mathrm{CO}$ in a manner similar to that of the LDV probe, described in the current report. Thus, a release of large amount of free heme and a subsequent $\mathrm{CO}$ production in macrophages will provide a protection of pathogens against microorganism clearance. However, no significant effect of exogenous heme administration on the number of bacterial colony-forming units in the blood and peritoneum of mice subjected to a nonlethal polymicrobial infection were found, and the ability of heme to precipitate sepsis was not directly related to the pathogen load [97]. Nevertheless, because hemolysis can be caused by pore-forming toxins produced by many blood-borne pathogens [103], the amount of free heme should be directly related to the bacterial load. The pore forming toxins are known to contribute to the evasion of host defence by the inhibition of innate immune responses in macrophages [104]. Thus, a number of immunological phenomena related to pathogen-induced hemolysis can be related to the regulation of VLA-4 integrinmediated binding of pattern recognition molecules, phagosome maturation and microorganism clearance in macrophages. The ability to release free heme, induce production of large amount of $\mathrm{CO}$, and thus block integrin-dependent cell adhesion could be one of the previously unrecognised immune evasion mechanisms employed by haemolytic pathogens.

\section{Conclusions}

We conclude that $\mathrm{CO}$ from an artificial donor or a natural CO source (hemin) down-modulated binding of the VLA-4 integrin-specific ligand at rest and after inside- out activation through several $\mathrm{G \alpha}_{\mathrm{i}}$-coupled receptors activation. This results in a rapid down-modulation of integrin-dependent cell adhesion. We propose that CO-triggered integrin deactivation represents a novel mechanism that provides a molecular basis for several phenomena related to the mobilization of different cell subsets, and the evasion of the immune response.

\section{Methods}

\section{Materials}

The VLA-4-specific ligand 4-((N'-2-methylphenyl)ureido)phenylacetyl-L-leucyl-L-aspartyl-L-valyl-L-prolyl-L-alanylL-alanyl-L-lysine (LDV) and its FITC-conjugated analog (LDV-FITC probe) [30,33] were synthesized at Commonwealth Biotechnologies. Mouse anti-human CD29/integrin $\beta_{1}$ chain, clone MAR4 (PE), mouse anti-human CD49d/ integrin $\alpha_{4}$ chain, clone 9F10 (PE), and isotype control (mouse IgG1 $\kappa, \mathrm{PE}$ ) clone MOPC-21 were purchased from $\mathrm{BD}$ Biosciences and used according to the instructions of the manufacturer. Human recombinant CXCL12/SDF-1 $\alpha$ and recombinant human CXCL8/IL-8 were obtained from R\&D Systems, Inc. All other reagents were from Sigma-Aldrich. Stock solutions were prepared in DMSO, at concentrations $\sim 1000$-fold higher than the final concentration. Usually, $1 \mu$ l of stock solution was added to $1 \mathrm{ml}$ of cell suspension, yielding a final $0.1 \%$ DMSO concentration. Control samples were treated with an equal amount of pure DMSO (vehicle).

\section{Cell lines and transfectant construct}

The human histiocytic lymphoma cell line U937 and mouse melanoma cell line B78H1 were purchased from ATCC. Wild type CXCR4 (CD184) receptor-stably transfected U937 cells, wild type CXCR2 (IL8RB)-stably transfected U937 cells, and the non-desensitizing FPR $\triangle$ ST mutant in U937 cells were prepared as described [105], and were a gift of Dr. Eric Prossnitz (University of New Mexico). For transfection of $\mathrm{B} 78 \mathrm{H} 1$ cells, full-length human VCAM-1 cDNA was a kind gift from Dr. Roy Lobb of Biogen. The original construct [106] was subcloned into the pTRACER vector (Life Technologies Corp.). Transfection into $\mathrm{B} 78 \mathrm{H} 1$ was done using the Lipofectamine transfection reagent (Life Technologies Corp). High receptor-expressing cells were sorted using a MoFlo flow cytometer (Beckman Coulter Inc.). Cells were grown at $37^{\circ} \mathrm{C}$ in a humidified atmosphere with 5\% CO2 and 95\% air in RPMI 1640 (supplemented with $2 \mathrm{mM}$ L-glutamine, 100 units $/ \mathrm{ml}$ penicillin, $100 \mu \mathrm{g} / \mathrm{ml}$ streptomycin, $10 \mathrm{mM}$ HEPES, pH 7.4, and 10\% heatinactivated fetal bovine serum). Cells were counted using the Coulter Multisizer/Z2 analyzer (Beckman Coulter Inc.). For experiments, cells were suspended in warm $\mathrm{RPMI}\left(37^{\circ} \mathrm{C}\right)$ at $1 \times 10^{6}$ cells $/ \mathrm{ml}$ and used immediately. 


\section{Kinetic analysis of binding and dissociation of VLA-4 specific ligand}

Kinetic analysis of the binding and dissociation of the LDV-FITC probe was described previously [30,33]. Briefly, cells $\left(1 \times 10^{6}\right.$ cells $\left./ \mathrm{ml}\right)$ were preincubated in warm RPMI under the appropriate conditions for $10-20 \mathrm{~min}$ at $37^{\circ} \mathrm{C}$. Flow cytometric data were acquired for up to $1024 \mathrm{~s}$ at $37^{\circ} \mathrm{C}$ while the samples were stirred continuously at $300 \mathrm{rpm}$ with a $5 \times 2 \mathrm{~mm}$ magnetic stir bar (Bel-Art Products). Samples were analyzed for 30-120 s to establish a baseline. The fluorescent ligand was added and acquisition was re-established, creating a 5-10 s gap in the time course. For real-time affinity activation experiments, $4 \mathrm{nM}$ LDV-FITC was added after establishing a baseline. Then, data were acquired for 2-3 minutes, and cells were treated with different GPCR ligands at saturating concentration (10 times or higher than $K_{d}$ ). In several experiments, cells were treated sequentially with two or more different compounds. Acquisition was re-established, and data were acquired continuously for up to $1024 \mathrm{~s}$.

The concentration of the LDV-FITC probe used in activation experiments $(4 \mathrm{nM})$ was below the dissociation constant $\left(\mathrm{K}_{\mathrm{d}}\right)$ for its binding to resting VLA-4 (low affinity state, $\mathrm{K}_{\mathrm{d}} \sim 12 \mathrm{nM}$ ), and above the $\mathrm{K}_{\mathrm{d}}$ for physiologically activated VLA-4 (high affinity state, $\mathrm{K}_{\mathrm{d}} \sim 1-2 \mathrm{nM}$ ) [30]. Therefore, the transition from the low affinity to the high affinity receptor state led to increased binding of the probe (from $\sim 25 \%$ to $\sim 70-80 \%$ of receptor occupancy, as calculated based on the one site binding equation), which was detected as an increase in the mean fluorescence intensity. For kinetic dissociation measurements, cell samples were preincubated with the fluorescent probe $(25 \mathrm{nM})$, treated with excess unlabeled LDV $(2 \mu \mathrm{M})$, and the dissociation of the fluorescent molecule was followed. The resulting data were converted to mean fluorescence intensity versus time using FCSQuery software developed by Dr. Bruce Edwards (University of New Mexico).

\section{Cell aggregation assay}

The cell suspension aggregation assay has been described previously [35,37]. Briefly, U937 cells were labeled with the green fluorescence PKH67GL dye, and B78H1/ VCAM-1 transfectants were stained with the red fluorescence PKH26GL dye (Sigma-Aldrich). Labeled cells were washed, resuspended in RPMI and stored on ice until used in the assays. Control U937 cells were preincubated with the LDV molecule for blocking. Prior to data acquisition, cells were warmed to $37^{\circ} \mathrm{C}$ for $10 \mathrm{~min}$ separately and then mixed. During data acquisition, the samples were stirred with a $5 \times 2-\mathrm{mm}$ magnetic stir bar (Bel-Art Products, Pequannock, NJ) at $300 \mathrm{rpm}$ and kept at $37^{\circ} \mathrm{C}$. The number of cell aggregates containing red and green co-fluorescent particles, and the number of singlets were followed in real-time. The percentage of aggregates (Agg, \%) was calculated as follows: Agg, \% = (number of aggregates/(number of aggregates + number of singlets) $) \times$ 100. Experiments were performed using a FACScan flow cytometer and Cell Quest software (Becton Dickinson, San Jose, CA). The real-time aggregation kinetic data were converted to Agg, \% versus time using FCSQuery software developed by Dr. Bruce Edwards (University of New Mexico). Figures were prepared using Summit V4.3 software (Beckman Coulter Inc.).

\section{Statistical analysis}

Curve fits and statistics were performed using GraphPad Prism version 4.00 for Windows, GraphPad Software, San Diego California USA, www.graphpad.com. Each experiment was repeated two or three times. The experimental curves represent the mean of two or more independent runs. SEM was calculated using GraphPad Prism.

\section{Abbreviations}

CO: Carbon monoxide; CORM-2: Carbon monoxide-releasing molecule 2, tricarbonyldichlororuthenium (II) dimer; dbcAMP: N-6,2'-O-dibutyryladenosine 3',5'-cyclic monophosphate; EPC: Endothelial progenitor cell; FITC: Fluorescein isothiocyanate; GC: Guanylyl cyclase; fMLFF: N-formyl-L-methionyl-L-leucyl-Lphenylalanyl-L-phenylalanine, formyl peptide; FPR: Formyl peptide receptor 1; GPCR: Guanine nucleotide binding protein coupled receptor; HEPES:

4-(2- hydroxyethyl)-1-piperazineethanesulfonic acid; HO: Heme oxygenase; HSPC: Hematopoietic stem progenitor cell; LDV: 4-((N'-2-methylphenyl)ureido)phenylacetyl-L-leucyl-L-aspartyl-L-valyl-L-prolyl-L-alanyl-L-alanyl-L-lysine; LDV-FITC: 4-((N'-2-methylphenyl)ureido)-phenylacetyl- L-leucyl-L-aspartyl-L-valylL-prolyl-L-alanyl-L-alanyl-L-lysine-FITC; LIBS: Ligand induced binding site; mAb: Monoclonal antibody; MCF: Mean channel fluorescence, equivalent of mean fluorescence intensity; NOS3 or eNOS: Endothelial nitric oxide synthase; SDF-1: Stromal cell-derived factor-1, CXCL12; VCAM-1: Vascular cell adhesion molecule 1, CD106; VLA-4: Very late antigen 4, CD49d/CD29, a4ß1 integrin; VLA-5: Very late antigen 5, CD49e/CD29, a5 31 integrin.

\section{Competing interests}

The authors declare that they have no competing interests.

\section{Authors' contributions}

AC designed the study and experiments, interpreted the experimental data, and wrote the manuscript; YS performed the experiments; LAS contributed to experimental design and manuscript preparation. All authors read and approved the final manuscript.

\section{Acknowledgements}

We thank Eric R. Prossnitz for providing cells and GPCR plasmids, Roy Lobb for providing VCAM-1 CDNA, Bruce S. Edwards for providing FCSQuery software, and George Tegos for fruitful scientific discussion. This work is supported by $\mathrm{NIH}$ grant R01HL081062 and U54MH084690 to LAS, and by Dedicated Health Research Funds of the University of New Mexico School of Medicine grant C-2297-RAC to AC.

\section{Author details}

${ }^{1}$ Department of Pathology and University of New Mexico Cancer Center, Albuquerque, NM 87131, USA. ${ }^{2}$ University of New Mexico Center for Molecular Discovery, Albuquerque, NM 87131, USA. ${ }^{3}$ University of New Mexico Health Sciences Center, Albuquerque, NM 87131, USA.

Received: 18 July 2014 Accepted: 21 October 2014

Published online: 31 October 2014

\section{References}

1. Verma A, Hirsch DJ, Glatt CE, Ronnett GV, Snyder SH: Carbon monoxide: a putative neural messenger. Science 1993, 259:381-384. 
2. Otterbein LE, Bach FH, Alam J, Soares M, Tao LH, Wysk M, Davis RJ, Flavell RA, Choi AM: Carbon monoxide has anti-inflammatory effects involving the mitogen-activated protein kinase pathway. Nat Med 2000, 6:422-428.

3. Ryter SW, Alam J, Choi AM: Heme oxygenase-1/carbon monoxide: from basic science to therapeutic applications. Physiol Rev 2006, 86:583-650

4. Ryter SW, Choi AM: Carbon monoxide: present and future indications for a medical gas. Korean J Intern Med 2013, 28:123-140

5. Rochette L, Cottin Y, Zeller M, Vergely C: Carbon monoxide: mechanisms of action and potential clinical implications. Pharmacol Ther 2013, 137:133-152.

6. Hanafy KA, Oh J, Otterbein LE: Carbon monoxide and the brain: time to rethink the dogma. Curr Pharm Des 2013, 19:2771-2775.

7. Snyder SH, Jaffrey SR, Zakhary R: Nitric oxide and carbon monoxide: parallel roles as neural messengers. Brain Res Brain Res Rev 1998, 26:167-175.

8. Chigaev A, Smagley Y, Sklar LA: Nitric oxide/cGMP pathway signaling actively down-regulates alpha4beta1-integrin affinity: an unexpected mechanism for inducing cell de-adhesion. BMC Immunol 2011, 12:28.

9. Chigaev A, Sklar LA: Aspects of VLA-4 and LFA-1 regulation that may contribute to rolling and firm adhesion. Front Immunol 2012, 3:242.

10. Askari JA, Buckley PA, Mould AP, Humphries MJ: Linking integrin conformation to function. J Cell Sci 2009, 122:165-170.

11. Ley K, Laudanna C, Cybulsky MI, Nourshargh S: Getting to the site of inflammation: the leukocyte adhesion cascade updated. Nat Rev Immunol 2007, 7:678-689

12. Gazitt Y: Homing and mobilization of hematopoietic stem cells and hematopoietic cancer cells are mirror image processes, utilizing similar signaling pathways and occurring concurrently: circulating cancer cells constitute an ideal target for concurrent treatment with chemotherapy and antilineage-specific antibodies. Leukemia 2004, 18:1-10.

13. Schneider JG, Amend SR, Weilbaecher KN: Integrins and bone metastasis: integrating tumor cell and stromal cell interactions. Bone 2011, 48:54-65.

14. Simon T, Pogu S, Tardif V, Rigaud K, Remy S, Piaggio E, Bach JM, Anegon I, Blancou P: Carbon monoxide-treated dendritic cells decrease beta1integrin induction on CD8(+) T cells and protect from type 1 diabetes. Eur J Immunol 2013, 43:209-218.

15. Dal Secco D, Freitas A, Abreu MA, Garlet TP, Rossi MA, Ferreira SH, Silva JS, Alves-Filho JC, Cunha FQ: Reduction of ICAM-1 expression by carbon monoxide via soluble guanylate cyclase activation accounts for modulation of neutrophil migration. Naunyn Schmiedebergs Arch Pharmacol 2010, 381:483-493.

16. Urquhart P, Rosignoli G, Cooper D, Motterlini R, Perretti M: Carbon monoxide-releasing molecules modulate leukocyte-endothelial interactions under flow. J Pharmacol Exp Ther 2007, 321:656-662.

17. Zhou JL, Wang QY, Du XR, Zhu XG, Ling YL, Liu QH: [Effect of exogenous carbon monoxide on sequestration of polymorphonuclear neutrophils in the lung following limb ischemia-reperfusion: an experimental study]. Zhonghua Yi Xue Za Zhi 2005, 85:1987-1990.

18. Moncure M, Chen L, Childs EW, Smalley D, Udobi KF, Cheung LY: Hemeoxygenase-1 mRNA expression affects hemorrhagic shock-induced leukocyte adherence. J Trauma 2003, 55:118-125.

19. Andersson JA, Egesten A, Cardell LO: Hemin, a heme oxygenase substrate analog, inhibits the cell surface expression of CD11b and CD66b on human neutrophils. Allergy 2002, 57:718-722.

20. Kim HP, Ryter SW, Choi AM: CO as a cellular signaling molecule. Annu Rev Pharmacol Toxicol 2006, 46:411-449.

21. Slebos DJ, Ryter SW, van der TM, Liu F, Guo F, Baty CJ, Karlsson JM, Watkins SC, Kim HP, Wang X, Lee JS, Postma DS, Kauffman HF, Choi AM: Mitochondrial localization and function of heme oxygenase-1 in cigarette smoke-induced cell death. Am J Respir Cell Mol Biol 2007, 36:409-417.

22. Wu L, Wang R: Carbon monoxide: endogenous production, physiological functions, and pharmacological applications. Pharmacol Rev 2005, 57:585-630.

23. Motterlini R: Carbon monoxide-releasing molecules (CO-RMs): vasodilatory, anti-ischaemic and anti-inflammatory activities. Biochem Soc Trans 2007, 35:1142-1146.

24. Motterlini R, Clark JE, Foresti R, Sarathchandra P, Mann BE, Green CJ: Carbon monoxide-releasing molecules: characterization of biochemical and vascular activities. Circ Res 2002, 90:E17-E24.

25. Sun B, Sun H, Liu C, Shen J, Chen Z, Chen X: Role of CO-releasing molecules liberated $\mathrm{CO}$ in attenuating leukocytes sequestration and inflammatory responses in the lung of thermally injured mice. J Surg Res 2007, 139:128-135.
26. Sun BW, Chen ZY, Chen X, Liu C: Attenuation of leukocytes sequestration by carbon monoxide-releasing molecules: liberated carbon monoxide in the liver of thermally injured mice. J Burn Care Res 2007, 28:173-181.

27. Ma JL, Yang PY, Rui YC, Lu L, Kang H, Zhang J: Hemin modulates cytokine expressions in macrophage-derived foam cells via heme oxygenase-1 induction. J Pharmaco/ Sci 2007, 103:261-266.

28. Straub A, Stasch JP, Alonso-Alija C, Benet-Buchholz J, Ducke B, Feurer A, Furstner C: NO-independent stimulators of soluble guanylate cyclase. Bioorg Med Chem Lett 2001, 11:781-784

29. Schwede F, Maronde E, Genieser H, Jastorff B: Cyclic nucleotide analogs as biochemical tools and prospective drugs. Pharmacol Ther 2000, 87:199-226.

30. Chigaev A, Blenc AM, Braaten JV, Kumaraswamy N, Kepley CL, Andrews RP Oliver JM, Edwards BS, Prossnitz ER, Larson RS, Sklar LA: Real time analysis of the affinity regulation of alpha 4-integrin. The physiologically activated receptor is intermediate in affinity between resting and $\mathrm{Mn}(2+)$ or antibody activation. J Biol Chem 2001, 276:48670-48678.

31. Chen LL, Whitty A, Lobb RR, Adams SP, Pepinsky RB: Multiple activation states of integrin alpha4beta1 detected through their different affinities for a small molecule ligand. J Biol Chem 1999, 274:13167-13175.

32. Lin K, Ateeg HS, Hsiung SH, Chong LT, Zimmerman CN, Castro A, Lee WC, Hammond CE, Kalkunte S, Chen LL, Pepinsky RB, Leone DR, Sprague AG, Abraham WM, Gill A, Lobb RR, Adams SP: Selective, tight-binding inhibitors of integrin alpha4beta1 that inhibit allergic airway responses. J Med Chem 1999, 42:920-934.

33. Chigaev A, Sklar LA: Overview: assays for studying integrin-dependent cell adhesion. Methods Mol Biol 2012, 757:3-14.

34. Chigaev A, Waller A, Amit O, Sklar LA: Galphas-coupled receptor signaling actively down-regulates alpha4beta1-integrin affinity: a possible mechanism for cell de-adhesion. BMC Immunol 2008, 9:26.

35. Chigaev A, Zwartz G, Graves SW, Dwyer DC, Tsuji H, Foutz TD, Edwards BS, Prossnitz ER, Larson RS, Sklar LA: Alpha4beta1 integrin affinity changes govern cell adhesion. J Biol Chem 2003, 278:38174-38182.

36. Newham P, Craig SE, Clark K, Mould AP, Humphries MJ: Analysis of ligandinduced and ligand-attenuated epitopes on the leukocyte integrin alpha4beta1: VCAM-1, mucosal addressin cell adhesion molecule-1, and fibronectin induce distinct conformational changes. J Immunol 1998 160:4508-4517.

37. Zwartz G, Chigaev A, Foutz T, Larson RS, Posner R, Sklar LA: Relationship between Molecular and Cellular Dissociation Rates for VLA-4/VCAM-1 Interaction in the Absence of Shear Stress. Biophys J 2004, 86:1243-1252.

38. Vines CM, Xue M, Maestas DC, Cimino DF, Prossnitz ER: Regulation of $\mathrm{N}$-formyl peptide-mediated degranulation by receptor phosphorylation. $\mathrm{J}$ Immunol 2002, 169:6760-6766.

39. Key TA, Foutz TD, Gurevich W, Sklar LA, Prossnitz ER: N-formyl peptide receptor phosphorylation domains differentially regulate arrestin and agonist affinity. J Biol Chem 2003, 278:4041-4047.

40. Prossnitz ER: Desensitization of $\mathrm{N}$-formylpeptide receptor-mediated activation is dependent upon receptor phosphorylation. J Biol Chem 1997, 272:15213-15219.

41. Chigaev A, Waller A, Amit O, Halip L, Bologa CG, Sklar LA: Real-time Analysis of Conformation-sensitive Antibody Binding Provides New Insights into Integrin Conformational Regulation. J Biol Chem 2009, 284:14337-14346

42. Sklar LA, Edwards BS, Graves SW, Nolan JP, Prossnitz ER: Flow cytometric analysis of ligand-receptor interactions and molecular assemblies. Annu Rev Biophys Biomol Struct 2002, 31:97-119.

43. Edwards BS, Oprea T, Prossnitz ER, Sklar LA: Flow cytometry for highthroughput, high-content screening. Curr Opin Chem Biol 2004, 8:392-398.

44. Megias J, Busserolles J, Alcaraz MJ: The carbon monoxide-releasing molecule CORM- 2 inhibits the inflammatory response induced by cytokines in Caco-2 cells. Br J Pharmacol 2007, 150:977-986.

45. Guillen MI, Megias J, Clerigues V, Gomar F, Alcaraz MJ: The CO-releasing molecule CORM-2 is a novel regulator of the inflammatory process in osteoarthritic chondrocytes. Rheumatology (Oxford) 2008, 47:1323-1328.

46. Reiter CE, Alayash Al: Effects of carbon monoxide (CO) delivery by a CO donor or hemoglobin on vascular hypoxia inducible factor 1alpha and mitochondrial respiration. FEBS Open Bio 2012, 2:113-118.

47. Sher EA, Shaklai M, Shaklai N: Carbon monoxide promotes respiratory hemoproteins iron reduction using peroxides as electron donors. PLOS ONE 2012, 7:e33039. 
48. Motterlini R, Sawle P, Hammad J, Bains S, Alberto R, Foresti R, Green CJ: CORM-A1: a new pharmacologically active carbon monoxide-releasing molecule. FASEB J 2005, 19:284-286.

49. Shokawa T, Yoshizumi M, Yamamoto H, Omura S, Toyofuku M, Shimizu Y, Imazu M, Kohno N: Induction of heme oxygenase-1 inhibits monocyte chemoattractant protein-1 mRNA expression in U937 cells. J Pharmacol Sci 2006, 100:162-166.

50. Turpaev K, Bouton C, Drapier JC: Nitric oxide-derived nitrosating species and gene expression in human monocytic cells. Biochemistry 2004, 43:10844-10850.

51. Miyazaki T, Kirino Y, Takeno M, Samukawa S, Hama M, Tanaka M, Yamaji S, Ueda A, Tomita N, Fujita H, Ishigatsubo Y: Expression of heme oxygenase-1 in human leukemic cells and its regulation by transcriptional repressor Bach1. Cancer Sci 2010, 101:1409-1416.

52. Nagai T, Kikuchi S, Ohmine K, Miyoshi T, Nakamura M, Kondo T, Furuyama K, Komatsu N, Ozawa K: Hemin reduces cellular sensitivity to imatinib and anthracyclins via Nrf2. J Cell Biochem 2008, 104:680-691.

53. Chigaev A, Waller A, Zwartz GJ, Buranda T, Sklar LA: Regulation of cell adhesion by affinity and conformational unbending of alpha4beta1 integrin. J Immunol 2007, 178:6828-6839.

54. Njus BH, Chigaev A, Waller A, Wlodek D, Ostopovici-Halip L, Ursu O, Wang W, Oprea TI, Bologa CG, Sklar LA: Conformational mAb as a tool for integrin ligand discovery. Assay Drug Dev Technol 2009, 7:507-515.

55. Chigaev A, Wu Y, Williams DB, Smagley Y, Sklar LA: Discovery of very late antigen-4 (VLA-4, \{alpha\}4\{beta\}1 integrin) allosteric antagonists. J Biol Chem 2011, 286:5455-5463.

56. Chigaev A, Zwartz GJ, Buranda T, Edwards BS, Prossnitz ER, Sklar LA: Conformational regulation of alpha 4 beta 1-integrin affinity by reducing agents. "Inside-out" signaling is independent of and additive to reductionregulated integrin activation. J Biol Chem 2004, 279:32435-32443.

57. Ryter SW, Morse D, Choi AM: Carbon monoxide: to boldly go where NO has gone before. Sci STKE 2004, 2004:RE6.

58. Beavo JA, Brunton LL: Cyclic nucleotide research - still expanding after half a century. Nat Rev Mol Cell Biol 2002, 3:710-718.

59. Dimitrov S, Shaikh F, Pruitt C, Green M, Wilson K, Beg N, Hong S: Differential TNF production by monocyte subsets under physical stress: blunted mobilization of proinflammatory monocytes in prehypertensive individuals. Brain Behav Immun 2013, 27:101-108.

60. Dimitrov S, Benedict C, Heutling D, Westermann J, Born J, Lange T: Cortisol and epinephrine control opposing circadian rhythms in T cell subsets. Blood 2009, 113:5134-5143.

61. Dimitrov S, Lange T, Born J: Selective mobilization of cytotoxic leukocytes by epinephrine. J Immunol 2010, 184:503-511.

62. Benschop RJ, Schedlowski M, Wienecke H, Jacobs R, Schmidt RE: Adrenergic control of natural killer cell circulation and adhesion. Brain Behav Immun 1997, 11:321-332.

63. Jetschmann JU, Benschop RJ, Jacobs R, Kemper A, Oberbeck R, Schmidt RE, Schedlowski M: Expression and in-vivo modulation of alpha- and betaadrenoceptors on human natural killer (CD16+) cells. J Neuroimmunol 1997, 74:159-164.

64. Schedlowski M, Hosch W, Oberbeck R, Benschop RJ, Jacobs R, Raab HR, Schmidt RE: Catecholamines modulate human NK cell circulation and function via spleen-independent beta 2-adrenergic mechanisms. J Immunol 1996, 156:93-99.

65. Bruynzeel I, van der Raaij LM, Willemze R, Stoof TJ: Pentoxifylline inhibits human T-cell adhesion to dermal endothelial cells. Arch Dermatol Res 1997, 289:189-193.

66. Benschop RJ, Rodriguez-Feuerhahn M, Schedlowski M: Catecholamine-induced leukocytosis: early observations, current research, and future directions. Brain Behav Immun 1996, 10:77-91.

67. Benschop RJ, Nijkamp FP, Ballieux RE, Heijnen CJ: The effects of beta-adrenoceptor stimulation on adhesion of human natural killer cells to cultured endothelium. Br J Pharmacol 1994, 113:1311-1316.

68. Alon $\mathrm{R}$, Shulman $\mathrm{Z}$ : Chemokine triggered integrin activation and actin remodeling events guiding lymphocyte migration across vascular barriers. Exp Cell Res 2011, 317:632-641.

69. Lapidot T, Petit I: Current understanding of stem cell mobilization: the roles of chemokines, proteolytic enzymes, adhesion molecules, cytokines, and stromal cells. Exp Hematol 2002, 30:973-981.

70. Lapidot T, Dar A, Kollet O: How do stem cells find their way home? Blood 2005, 106:1901-1910.
71. Bonig H, Wundes A, Chang KH, Lucas S, Papayannopoulou T: Increased numbers of circulating hematopoietic stem/progenitor cells are chronically maintained in patients treated with the CD49d blocking antibody natalizumab. Blood 2008, 111:3439-3441.

72. Bonig H, Watts KL, Chang KH, Kiem HP, Papayannopoulou T: Concurrent blockade of alpha4-integrin and CXCR4 in hematopoietic stem/progenitor cell mobilization. Stem Cells 2009, 27:836-837.

73. Zohren F, Toutzaris D, Klarner V, Hartung HP, Kieseier B, Haas R: The monoclonal anti-VLA-4 antibody natalizumab mobilizes CD34+ hematopoietic progenitor cells in humans. Blood 2008, 111:3893-3895.

74. Papayannopoulou T, Nakamoto B: Peripheralization of hemopoietic progenitors in primates treated with anti-VLA4 integrin. Proc Natl Acad Sci U S A 1993, 90:9374-9378.

75. Ramirez P, Rettig MP, Uy GL, Deych E, Holt MS, Ritchey JK, DiPersio JF: BIO5192, a small molecule inhibitor of VLA-4, mobilizes hematopoietic stem and progenitor cells. Blood 2009, 114:1340-1343.

76. Dar A, Schajnovitz A, Lapid K, Kalinkovich A, Itkin T, Ludin A, Kao WM, Battista M, Tesio M, Kollet O, Cohen NN, Margalit R, Buss EC, Baleux F, Oishi S, Fujii N, Larochelle A, Dunbar CE, Broxmeyer HE, Frenette PS, Lapidot T: Rapid mobilization of hematopoietic progenitors by AMD3100 and catecholamines is mediated by CXCR4-dependent SDF-1 release from bone marrow stromal cells. Leukemia 2011, 25:1286-1296.

77. Lapid K, Itkin T, D'Uva G, Ovadya Y, Ludin A, Caglio G, Kalinkovich A, Golan K, Porat Z, Zollo M, Lapidot T: GSK3beta regulates physiological migration of stem/progenitor cells via cytoskeletal rearrangement. J Clin Invest 2013, 123:1705-1717.

78. Kollet O, Shivtiel S, Chen YQ, Suriawinata J, Thung SN, Dabeva MD, Kahn J, Spiegel A, Dar A, Samira S, Goichberg P, Kalinkovich A, Arenzana-Seisdedos F, Nagler A, Hardan I, Revel M, Shafritz DA, Lapidot T: HGF, SDF-1, and MMP-9 are involved in stress-induced human CD34+ stem cell recruitment to the liver. J Clin Invest 2003, 112:160-169.

79. Aicher A, Heeschen C, Mildner-Rihm C, Urbich C, Ihling C, Technau-Ihling K, Zeiher AM, Dimmeler S: Essential role of endothelial nitric oxide synthase for mobilization of stem and progenitor cells. Nat Med 2003, 9:1370-1376.

80. Holmes K, Roberts OL, Thomas AM, Cross MJ: Vascular endothelial growth factor receptor-2: structure, function, intracellular signalling and therapeutic inhibition. Cell Signal 2007, 19:2003-2012.

81. Moore MA, Hattori K, Heissig B, Shieh JH, Dias S, Crystal RG, Rafii S: Mobilization of endothelial and hematopoietic stem and progenitor cells by adenovector-mediated elevation of serum levels of SDF-1, VEGF, and angiopoietin-1. Ann N Y Acad Sci 2001, 938:36-45.

82. Aicher A, Heeschen C, Dimmeler S: The role of NOS3 in stem cell mobilization. Trends Mol Med 2004, 10:421-425.

83. Dimmeler S, Fleming I, Fisslthaler B, Hermann C, Busse R, Zeiher AM: Activation of nitric oxide synthase in endothelial cells by Akt-dependent phosphorylation. Nature 1999, 399:601-605

84. Fulton D, Gratton JP, McCabe TJ, Fontana J, Fujio Y, Walsh K, Franke TF, Papapetropoulos A, Sessa WC: Regulation of endothelium-derived nitric oxide production by the protein kinase Akt. Nature 1999, 399:597-601.

85. Papapetropoulos A, Garcia-Cardena G, Madri JA, Sessa WC: Nitric oxide production contributes to the angiogenic properties of vascular endothelial growth factor in human endothelial cells. J Clin Invest 1997, 100:3131-3139.

86. Ozuyaman B, Ebner P, Niesler U, Ziemann J, Kleinbongard P, Jax T, Godecke A, Kelm M, Kalka C: Nitric oxide differentially regulates proliferation and mobilization of endothelial progenitor cells but not of hematopoietic stem cells. Thromb Haemost 2005, 94:770-772.

87. Mebius RE, Kraal G: Structure and function of the spleen. Nat Rev Immunol 2005, 5:606-616.

88. Kovtunovych G, Eckhaus MA, Ghosh MC, Ollivierre-Wilson H, Rouault TA: Dysfunction of the heme recycling system in heme oxygenase 1-deficient mice: effects on macrophage viability and tissue iron distribution. Blood 2010, 116:6054-6062.

89. Swirski FK, Nahrendorf M, Etzrodt M, Wildgruber M, Cortez-Retamozo V, Panizzi P, Figueiredo JL, Kohler RH, Chudnovskiy A, Waterman P, Aikawa E, Mempel TR, Libby P, Weissleder R, Pittet MJ: Identification of splenic reservoir monocytes and their deployment to inflammatory sites. Science 2009, 325:612-616.

90. Gaillard CA, Schiffelers RM: Red blood cell: barometer of cardiovascular health? Cardiovasc Res 2013, 98:3-4.

91. Mo RR, Eisenbraun JK, Sonstein J, Craig RA, Curtis JL, Stoolman LM, Chen J, Yung RL: CD49d overexpression and T cell autoimmunity. J Immuno 2003, 171:745-753. 
92. Jaeschke $\mathrm{H}$ : Molecular mechanisms of hepatic ischemia-reperfusion injury and preconditioning. Am J Physiol Gastrointest Liver Physiol 2003, 284:G15-G26.

93. Yilmaz G, Granger DN: Cell adhesion molecules and ischemic stroke. Neurol Res 2008, 30:783-793.

94. Duarte S, Shen XD, Fondevila C, Busuttil RW, Coito AJ: Fibronectinalpha4beta1 interactions in hepatic cold ischemia and reperfusion injury: regulation of MMP-9 and MT1-MMP via the p38 MAPK pathway. Am J Transplant 2012, 12:2689-2699.

95. Otterbein LE, Zuckerbraun BS, Haga M, Liu F, Song R, Usheva A, Stachulak C, Bodyak N, Smith RN, Csizmadia E, Tyagi S, Akamatsu Y, Flavell RJ, Billiar TR, Tzeng E, Bach FH, Choi AM, Soares MP: Carbon monoxide suppresses arteriosclerotic lesions associated with chronic graft rejection and with balloon injury. Nat Med 2003, 9:183-190.

96. Schaer DJ, Buehler PW, Alayash Al, Belcher JD, Vercellotti GM: Hemolysis and free hemoglobin revisited: exploring hemoglobin and hemin scavengers as a novel class of therapeutic proteins. Blood 2013, 121:1276-1284.

97. Larsen R, Gozzelino R, Jeney V, Tokaji L, Bozza FA, Japiassu AM, Bonaparte D, Cavalcante MM, Chora A, Ferreira A, Marguti I, Cardoso S, Sepulveda N, Smith A, Soares MP: A central role for free heme in the pathogenesis of severe sepsis. Sci Transl Med 2010, 2:51ra71.

98. Wang QQ, Li H, Oliver T, Glogauer M, Guo J, He YW: Integrin beta 1 regulates phagosome maturation in macrophages through Rac expression. J Immunol 2008, 180:2419-2428.

99. Jia W, Li H, He YW: The extracellular matrix protein mindin serves as an integrin ligand and is critical for inflammatory cell recruitment. Blood 2005, 106:3854-3859.

100. Li Y, Cao C, Jia W, Yu L, Mo M, Wang Q, Huang Y, Lim JM, Ishihara M, Wells L, Azadi P, Robinson H, He WW, Zhang L, Mariuzza RA: Structure of the F-spondin domain of mindin, an integrin ligand and pattern recognition molecule. EMBO J 2009, 28:286-297.

101. Humphries JD, Byron A, Humphries MJ: Integrin ligands at a glance. J Cell Sci 2006, 119:3901-3903

102. He YW, Li H, Zhang J, Hsu CL, Lin E, Zhang N, Guo J, Forbush KA, Bevan MJ: The extracellular matrix protein mindin is a pattern-recognition molecule for microbial pathogens. Nat Immunol 2004, 5:88-97.

103. Bhakdi S, Bayley H, Valeva A, Walev I, Walker B, Kehoe M, Palmer M: Staphylococcal alpha-toxin, streptolysin-O, and Escherichia coli hemolysin: prototypes of pore-forming bacterial cytolysins. Arch Microbiol 1996, 165:73-79.

104. Bebien M, Hensler ME, Davanture S, Hsu LC, Karin M, Park JM, Alexopoulou L, Liu GY, Nizet $V$, Lawrence T: The pore-forming toxin beta hemolysin/ cytolysin triggers p38 MAPK-dependent IL-10 production in macrophages and inhibits innate immunity. PLoS Pathog 2012, 8:e1002812.

105. Kew RR, Peng T, DiMartino SJ, Madhavan D, Weinman SJ, Cheng D, Prossnitz ER: Undifferentiated U937 cells transfected with chemoattractant receptors: a model system to investigate chemotactic mechanisms and receptor structure/function relationships. J Leukoc Biol 1997, 61:329-337.

106. Osborn L, Hession C, Tizard R, Vassallo C, Luhowskyj S, Chi-Rosso G, Lobb R: Direct expression cloning of vascular cell adhesion molecule 1, a cytokine-induced endothelial protein that binds to lymphocytes. Cell 1989, 59:1203-1211.

doi:10.1186/s12865-014-0052-1

Cite this article as: Chigaev et al.: Carbon monoxide down-regulates a4 $\beta 1$ integrin-specific ligand binding and cell adhesion: a possible mechanism for cell mobilization. BMC Immunology 2014 15:52.

\section{Submit your next manuscript to BioMed Central and take full advantage of:}

- Convenient online submission

- Thorough peer review

- No space constraints or color figure charges

- Immediate publication on acceptance

- Inclusion in PubMed, CAS, Scopus and Google Scholar

- Research which is freely available for redistribution

Submit your manuscript at www.biomedcentral.com/submit 